\title{
О НЕКОТОРЫХ ОСОБЕННОСТЯХ СТРУКТУРЫ И ФУНКЦИОНИРОВАНИЯ ГОРНЫХ ТРОПИЧЕСКИХ ЛЕСНЫХ ЛАНДШАФТОВ ЦЕНТРАЛЬНОГО ВЬЕТНАМА И НЕОБХОДИМОСТИ СОЗДАНИЯ ЛАНДШАФТНО- ЭКОЛОГИЧЕСКОГО СТАЦИОНАРА \\ Горбунов Р.В. ${ }^{1,2,3}$, Кузнецов А.Н. ${ }^{1,4}$, Лебедев Я.О. ${ }^{3}$, Горбунова Т.Ю. ${ }^{3}$, Котлов И.П. ${ }^{1,4}$, Хой Н.Д. 1 \\ ${ }^{I}$ Совместный Российско-Вьетнамский Тропический научно-исследовательский и технологический центр, Ханой, Сочиалистическая Республика Вьетнам \\ ${ }^{2}$ ФБУУН «Институт морских биологических исследований имени А.О. Ковалевского РАН», 2. Севастополь, Российская Федерация \\ ${ }^{3}$ ФГБУН «Карадагская научная станиия им. Т.И.Вяземского - природный заповедник РАН» 2. Феодосия, пгт Курортное, Российская Федераџия \\ ${ }^{4}$ ФГБУН Институт проблем экологии и эволючии им. А.Н. Северияова РАН, 2. Москва, Российская Федерачия e-mail:karadag_station@mail.ru,forestkuz@mail.ru,ya.o.lebedev@yandex.ru, gorbunovatyu@gmail.com,ikotlov@gmail.com,danghoi110@gmail.com.
}

В работе обобщены результаты экспедиционных ландшафтных исследований на территории Южного Вьетнама (национальный парк Бидуп-Нуйба). Получены новые сведения о некоторых закономерностях структуры и функционирования горных тропических лесных экосистем. Представлены картографические материалы, иллюстрирующие компонентную структуру ландшафтов на топологическом уровне. Охарактеризованы факторы и условия формирования ландшафтов, морфологическая структура ландшафтов в пределах ключевого участка. Предложена сеть точек и программа мониторинговых работ на базе проектируемого Бидупского ландшафтно-экологического стационара.

Ключевые слова: ландшафт, экосистема, структура ландшафтов, функционирование ландшафтов, ландшафтно-экологический стационар, Бидуп-Нуйба, Вьетнам

\section{Введение}

Исследование горных ландшафтов имеет свои особенности, связанные с проявлением множества не столь характерных для условий равнинных территорий эффектов как высотная поясность, склоновая микрозональность, позиционность и др. Кроме того, в условиях складчатого рельефа формируются совершенно особые единицы морфологической структуры ландшафтов (стрии), связанные с высокой мозаичностью литологического строения в пределах одного высотного пояса (высотной местности). Исследованиям горных ландшафтов территории бывшего Советского Союза (умеренный, степной, пустынный климатические пояса) занимается ряд научных школ. Стационарные исследования особенностей структуры и функционирования горных ландшафтов в условиях тропического климата в русскоязычной литературе не упоминаются.

$$
\text { Целью работы является выявление особенностей структуры и }
$$
функционирования горных и предгорных ландшафтов в условиях тропического и субэкваториального типов климата. Объектом исследований является территория Вьетнама, где расположен Совместный Российско-Вьетнамский Тропический научно- 
исследовательский и технологический центр, а соответственно, имеется материальнотехническая база для проведения исследований.

Программа исследований включает два основных направления:

1. Изучение структуры горных ландшафтов территории Вьетнама;

2. Изучение функционирования основных типов ландшафтов.

Первое направление предполагает в долгосрочной перспективе исследование вертикальной, горизонтальной структуры ландшафтов и структуры межкомпонентных связей. Кроме того, планируется описание особенностей проявления высотной поясности, склоновой микрозональности, позиционные эффекты в формировании структуры горных ландшафтов. Одним из итогов этого исследования будет разработка ландшафтной карты территории Вьетнама на основе современных представлений о структуре горных ландшафтов.

Второе направление связано с изучением функционирования основных типов экосистем (радиационного, теплового и водного балансов). Для изучения функционирования необходимо создание сети ландшафтно-экологических стационаров в основных типах экосистем, обеспечивающих автоматическую регистрацию ландшафтно-экологических параметров (температура воздуха на высотах 0,5 и 2 м, температуры воздуха под пологом леса с регулярным шагом под пологом леса и над кронами, температура почвы на различной глубине, температура в лесной подстилке и в травяном ярусе, приходящая прямая и рассеянная солнечная радиация на поверхности крон деревьев, на поверхность почвы, затенение солнечной радиации пологом леса, отражённая радиация, количество атмосферных осадков, поверхностный сток, испарение с поверхности почвы, транспирация, влажность почвы на различных глубинах, влажность лесной подстилки, влажность воздуха, фенология растительных сообществ, прирост биомассы и др.).

В текущем году выполнена подготовительная работа по обоснованию территории ландшафтно-экологического стационара в Национальном парке Бидуп-Нуйба.

Работа выполнена в Совместном Российско-Вьетнамском Тропическом научноисследовательском и технологическом центре.

\section{Территория исследований}

Национальный парк (НП) Бидуп-Нуйба основан в 2004 году и назван по двум самым высоким вершинам плато Лангбиан: Бидуп (2287 м) и Нуй Ба (2167 м). Парк общей площадью 70038 га является одним из пяти крупнейших национальных парков во Вьетнаме. НП Бидуп-Нуйба расположен в южной части Вьетнама (рис. 1) и занимает территорию южной оконечности Контумского тектонического блока. Территория парка сложена юрскими и меловыми вулканическими породами различного литологического состава, перекрытыми мощной корой выветривания, сохранность которой обеспечивает практически полное отсутствие эрозионных процессов на склонах, покрытых сомкнутым тропическим лесом, почвы под которым переводят воду атмосферных осадков в вертикальный сток. В горном массиве сформировались полидоминантные смешанные леса со сложной (4 подъяруса) и среднесложной (3 подъяруса) вертикальной структурой древостоев - на выположенных участках и пологих склонах, и с простой (1-2 подъяруса) структурой на гребнях хребтов, вершинах и крутых склонах. Лесные древостои сложены лиственными деревьями из сем. Magnoliaceae, Theacea, Sapindaceae, Betulaceae, Fagaceae, Elaeocarpaceae, Hamamelidaceae, Altingiaceae, Schisandraceae, Cornaceae, Anacardiaceae, Pentaphylaceae, Malvaceae, Palmae, a также хвойными из Pinaceae (Pinus kesyia, P. dalatensis, P. krempfii, Keteleeria evelyniana,) Podocarpaceae (Dacrycarpus imbricatus, Dacrydium elatum, Nageia wallichiana) и Cupressaceae (Fokienia hodginsii) (Кузнецов и др., 2006; Кузнецов, 2013, 2016). 


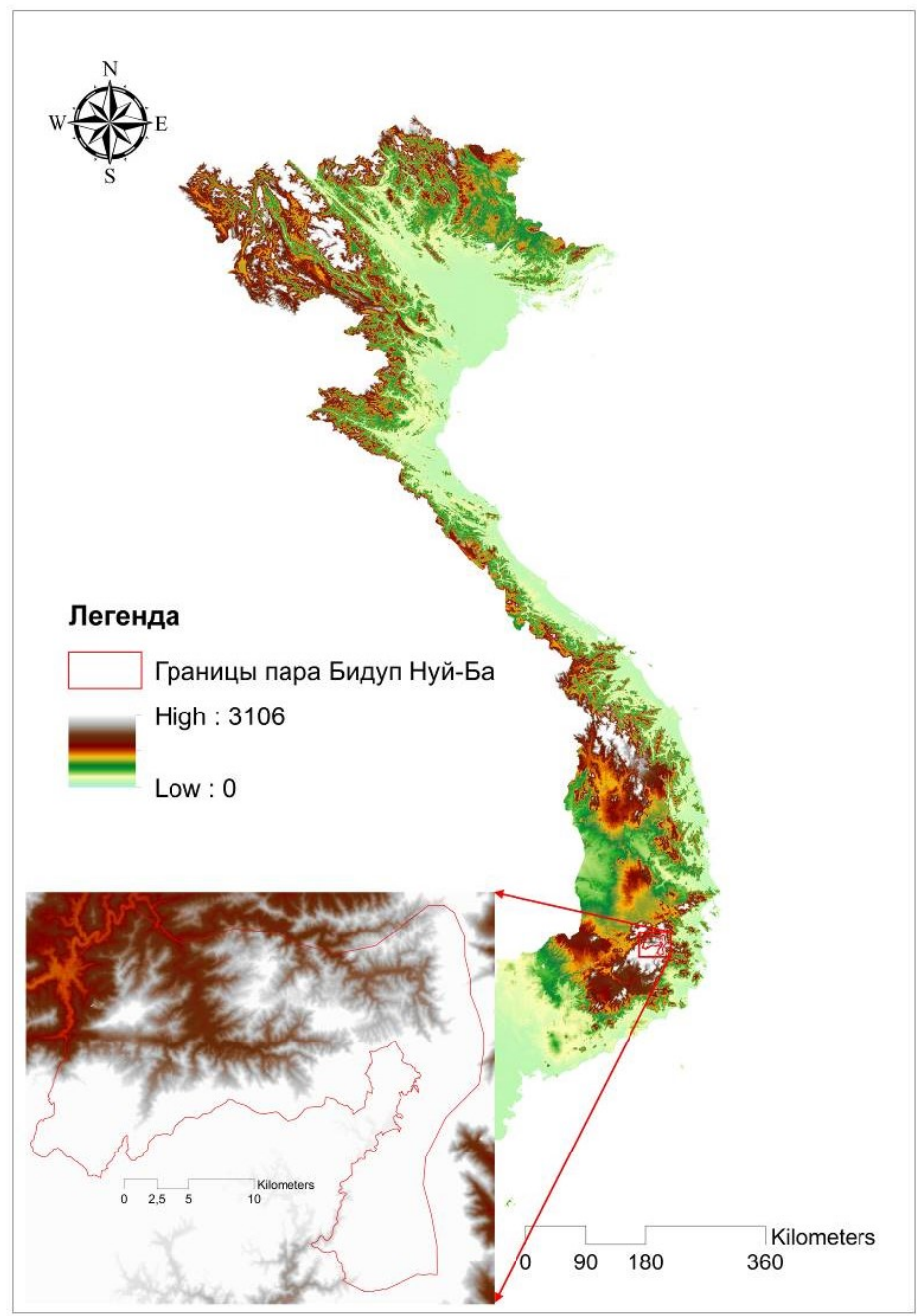

Рис. 1. Географическое положение НП Бидуп-Нуйба. Картографическая основа ЦMP SRTM

Анализ картографических материалов (топографической карты масштаба 1:100000, геологической карты, карты растительности), а также общедоступной цифровой модели рельефа (ЦМР) SRTM (пространственное разрешение 30 м), позволил выявить границы ландшафтов в пределах парка (рис. 2). Границы ландшафтов выявлены на основе представлений о ведущей роли геолого-геоморфологического строения в пространственной дифференциации ландшафтов.

Выявление границ ландшафтов осуществлялось путём соотнесения текстуры рельефа с геологической картой по методике, описанной в работах (Миллер, 1974; Круглов, 2008). На основе полученной карты-гипотезы предложены трансекты для полевого профилирования, и территория поиска ключевого участка для ландшафтноэкологического стационара, на которую составлена предварительная ландшафтная карта на уровне сложных урочищ. В процессе полевых исследований выявлено несоответствие генерализации карты ее масштабу (Котлов и др., 2018), в результате чего границы проектируемого стационара и трансекты скорректированы.

Определённый в ходе полевых исследований ключевой участок находится в восточном секторе НП Бидуп-Нуйба в границах Бидупского ландшафта (№ 3 на рис. 2). Координаты $108.700 \mathrm{E}, 12.170 \mathrm{~N}-108.705 \mathrm{E}, 12.175 \mathrm{~N}$. Площадь участка 17,9 га. Перепад высот от 1483 до 1579 м н.у.м. Участок представляет собой днище долины ручья с протокой, отходящей и вновь примыкающей к основному руслу вследствие меандрирования. Вероятно, протока представляет собой старый участок русла, в 
настоящий момент трансформирующийся в старицу. Пространственные размеры сформированного между руслом и протокой острова (осередка) составляют 90 м в ширину и 210 в длину (рис. 3).

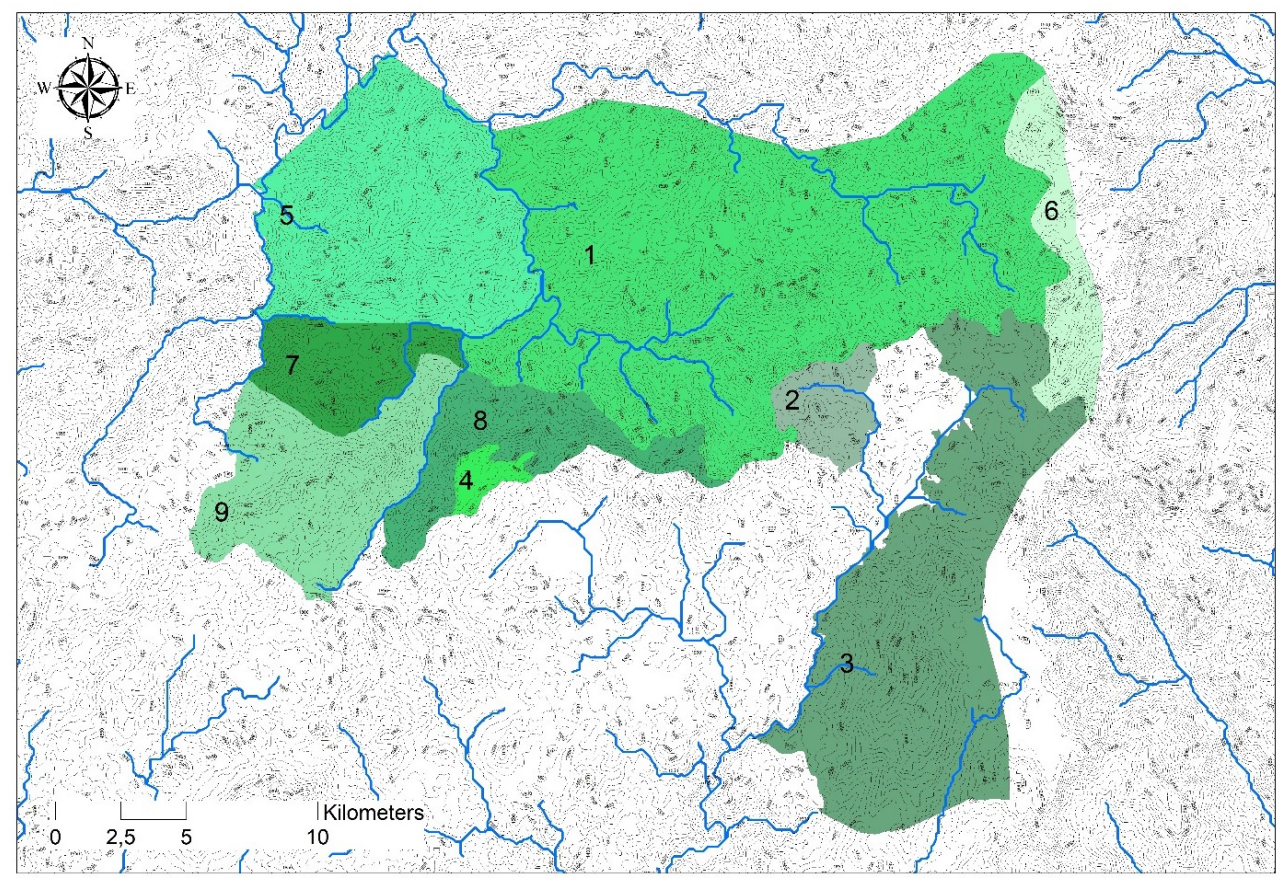

Рис. 2. Ландшафтная структура НП Бидуп-Нуйба. Картографическая основа гидрографическая сеть
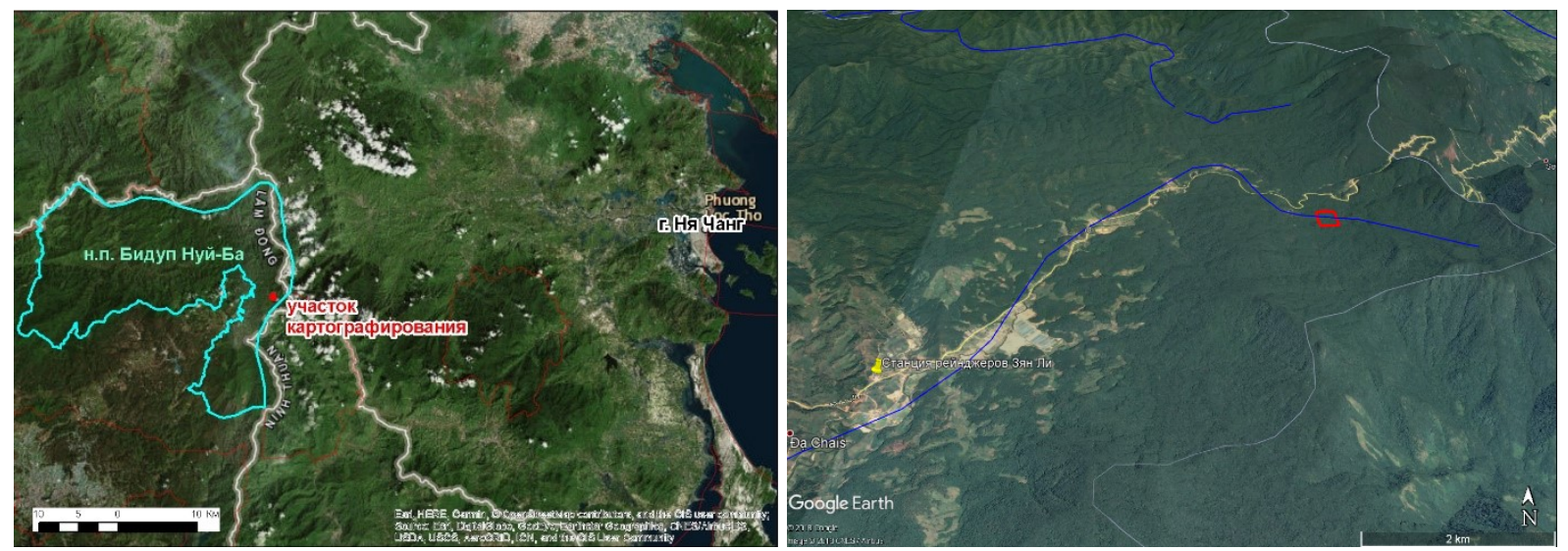

Рис 3. Изучаемая территория в НП Бидуп-Нуйба. Линией голубого цвета обозначены границы НП. Справа - площадка исследования в среднем масштабе

\section{Материалы и методы}

Полевая крупномасштабная ландшафтная съемка традиционно осуществляется в три этапа: подготовительный, полевой и камеральный (Видина, 1962; Миллер, 1974; Геренчук, Раковська, Топчієв, 1975; Жучкова, 1977; Дроздов, 1986 и др.). На подготовительном этапе проводится изучение литературного материала, имеющихся картографических произведений, фондовых материалов и пр., намечаются маршруты, трансекты, точки комплексных фациальных описаний, строится ландшафтная картагипотеза. В дополнение к собранным материалам на полевом этапе производится аэрофотосъемка местности с применением беспилотного летательного аппарата 
(БПЛА) и разработка высокоточного ортофотоплана территории и цифровой модели поверхности (ЦМП).

На камеральном этапе осуществляется обработка полученного материала и строится крупномасштабная ландшафтная карта. Такой подход апробирован для условий территории Российской Федерации и бывшего СССР. Материалы беспилотной аэросъемки в этом аспекте используются обычно на подготовительном этапе для создания карты-гипотезы.

Однако опыт работ в горных тропических лесах Центрального и Южного Вьетнама показал, что классические подходы к построению полевой ландшафтной карты на уровне фаций не всегда реализуемы, что связано с особенностями горизонтальной и вертикальной структуры ландшафта. Кроме того, выявлена практическая невозможность осуществления ландшафтного картирования без применения дистанционных методов исследования (Котлов и др., 2018).

\section{Результаты и обсуждения}

Особенности компонентной структуры ландшафтов. Территория ключевого участка сложена, согласно геологической карте, верхнемеловыми дацитами, риодацитами, риолитами, фельзитами, андезитодацитами, туфами. Дочетвертичные отложения перекрыты мощной корой выветривания, мощность которой в окрестностях ключевого участка варьируется в пределах $10^{-1} \times \mathrm{n}-10^{1} \times \mathrm{n}$ м. Непосредственно на самом ключевом участке мощность коры выветривания составляет от нескольких до 30-50 см. При этом в ходе маршрутов авторы отмечаали мощные коры выветривания в 10-15 м, как правило, в разрезах добычных карьеров. При условии одинакового возраста кор выветривания столь большая разница может говорить о существенно различной устойчивости разных материнских пород к выветриванию.

На рис. 4 представлена карта генетических типов рельефа территории ключевого участка.

В целом, для территории проектируемого стационара характерны следующие генетические типы рельефа:

1. Структурно-денудационный рельеф - представлен междолинными грядами, склонами структурных гряд, вершинами гребней, подошвами склонов, седловинами, террассами, которые формируют водосборные понижения и создают возможность формированию ложбин. Овражная сеть или эрозионное расчленение склонов практически отсутствует. Склоны как правило выпукло-вогнутой формы. Кроме того, следует отметить формирование структурных ложбин, связанных с изменением экспозиции склонов структурной гряды. В этом случае формируется структурный перегиб толщи пород и возникают условия для концентрации поверхностного стока.

2. Структурно-эрозионный рельеф - представлен ложбинами стока, водосборными понижениями, а также конусами выноса ложбин. Днище ложбин как правило перекрыто плащом делювиально-пролювиальных отложений. В целом, следует отметить, что формирование эрозионных форм рельефа приурочено на исследуемой территории к наличию временного водотока. Ложбины узкие, вытянутые вдоль склона, часто с высокими крутыми бортами с выходами скальных пород. В днище наблюдается наличие периодического руслового процесса, который протекает, вероятно, в сезон дождей. Слабо врезанные ложбины часто не достигают базиса эрозии и теряются в пределах поймы или структурной террасы.

3. Структурно-флювиальный рельеф - представлен руслом реки, бортами русла, порогами реки, осерёдками, сложенными аллювиальными отложениями, речной поймой. К структурно-флювиальному типу рельефа может быть отнесён и остров в русле реки, сформировавшийся на выходе коренной породы и затем увеличивший свою 

ХОЙ Н.Д.

площадь за счёт аллювиальных речных отложений. Восточная сторона острова сложена конгломератом, состоящим из слабосценментированного аллювия. Мысы острова сложены более молодыми аллювиальными отложениями.

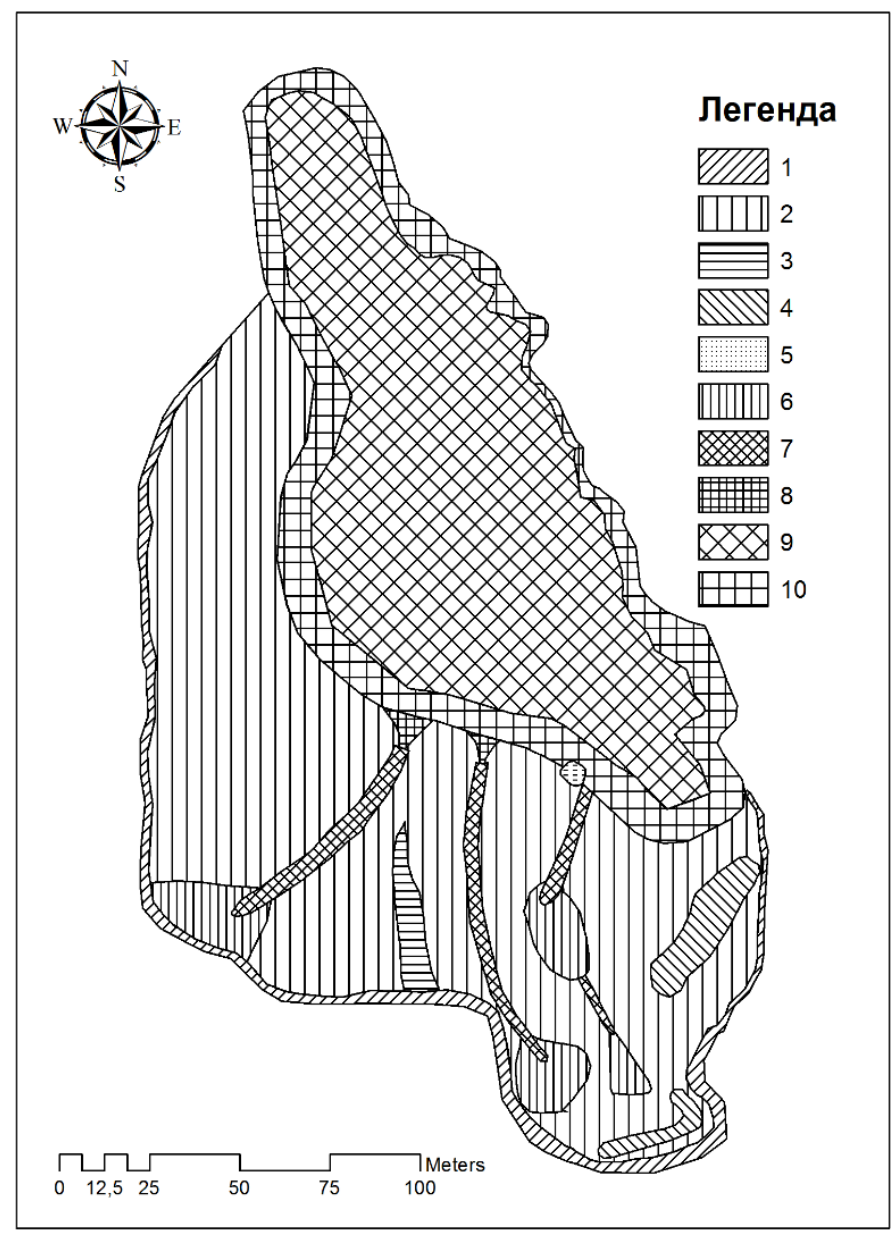

Рис. 4. Генетические типы рельефа: структурно-денудационный рельеф: 1 гребень структурной гряды; 2 - склоны структурной гряды; 3 - поверхность гребня межложбинной гряды; 4 - структурные террасы; 5 - скальный отторженец; структурноэрозионный рельеф: 6 - водосборные понижения на поверхности структурных гряд; 7 ложбины; 8 - конусы выноса; структурно-флювиальный рельеф: 9 - остров; 10 - русло реки

Климат Вьетнама тропический муссонный, специфика климата территории горного массива с вершиной Бидуп - определяется следующими факторами: относительной близостью морской акватории, меридиональным положением главного горного хребта, соседством с горными массивами Чуянгсин (на севере) и Хонба (на юго-востоке) и высокой облесенностью. Среднегодовое количество осадков около 2000 мм (Bioclimatic diagrams ..., 2000), регулярные атмосферные осадки (преимущественно ливневого характера) выпадают с сентября по ноябрь, ливни отмечаются также в период с середины мая по июнь, для остального времени года - моросящие дожди нерегулярного характера и разной продолжительности. Сведения о среднемесячных, максимальных и минимальных суточных температурах и влажности воздуха под пологом горного смешанного леса представлены в табл. 1. Сбор данных проводился Кузнецовым А.Н. и Кузнецовой С.П. с использованием портативных дата-логеров, установленных на участке леса (высота деревьев 25-30 м, структура древостоя 
сформирована тремя подъярусами) на высоте 1 м от поверхности почвы, высота над уровнем моря $1500 \mathrm{M}$.

Таблица 1.

Температура и влажность воздуха под пологом смешанного горного леса с января по октябрь, 2009г.

\begin{tabular}{|l|c|c|c|c|c|c|c|c|c|c|}
\hline \multicolumn{1}{|c|}{ Месяцы } & I & II & III & IV & V & VI & VII & VIII & IX & X \\
\hline Средняя t ${ }^{\circ} \mathrm{C}$ & 13,7 & 15,0 & 16,2 & 17,2 & 17,9 & 19,0 & 18,1 & 18,3 & 18,0 & 17,5 \\
\hline max $\mathrm{t}^{\circ} \mathrm{C}$ & 28,0 & 23,0 & 24,5 & 25,0 & 22,0 & 25,5 & 25,5 & 23,5 & 23,0 & 24,5 \\
\hline${\text { min }{ }^{\circ} \mathrm{C}}_{\text {Средняя W\% }} 5,0$ & 4,5 & 7,0 & 12,5 & 14,5 & 14,0 & 13,0 & 13,0 & 14,5 & 14,0 \\
\hline min W\% & 93,0 & 96,3 & 95,9 & 99,1 & 97,5 & 96,9 & 98,8 & 98,8 & 100,0 & 99,6 \\
\hline
\end{tabular}

Из таблицы следует, что среднемесячные температуры под пологом горного леса не превышают $19^{\circ} \mathrm{C}$, средние показатели относительной влажности не ниже $93 \%$. В период с декабря по первую половину марта температура воздуха в ночное время иногда опускается ниже $5-7^{\circ} \mathrm{C}$.

Экспедиция 2018 года проводилась в конце марта - начале апреля. На территории лесного кордона Зянг Ли был установлен портативный дата-логер, который позволил провести первичные измерения основных метеорологических показателей. Измерения проводились с 24.03.2018 г. по 31.03.2018 г. с периодичностью каждые 30 минут. Далее данные усреднялись до часа. На рис. 5 и 6 представлены графики изменений регистрируемых показателей.

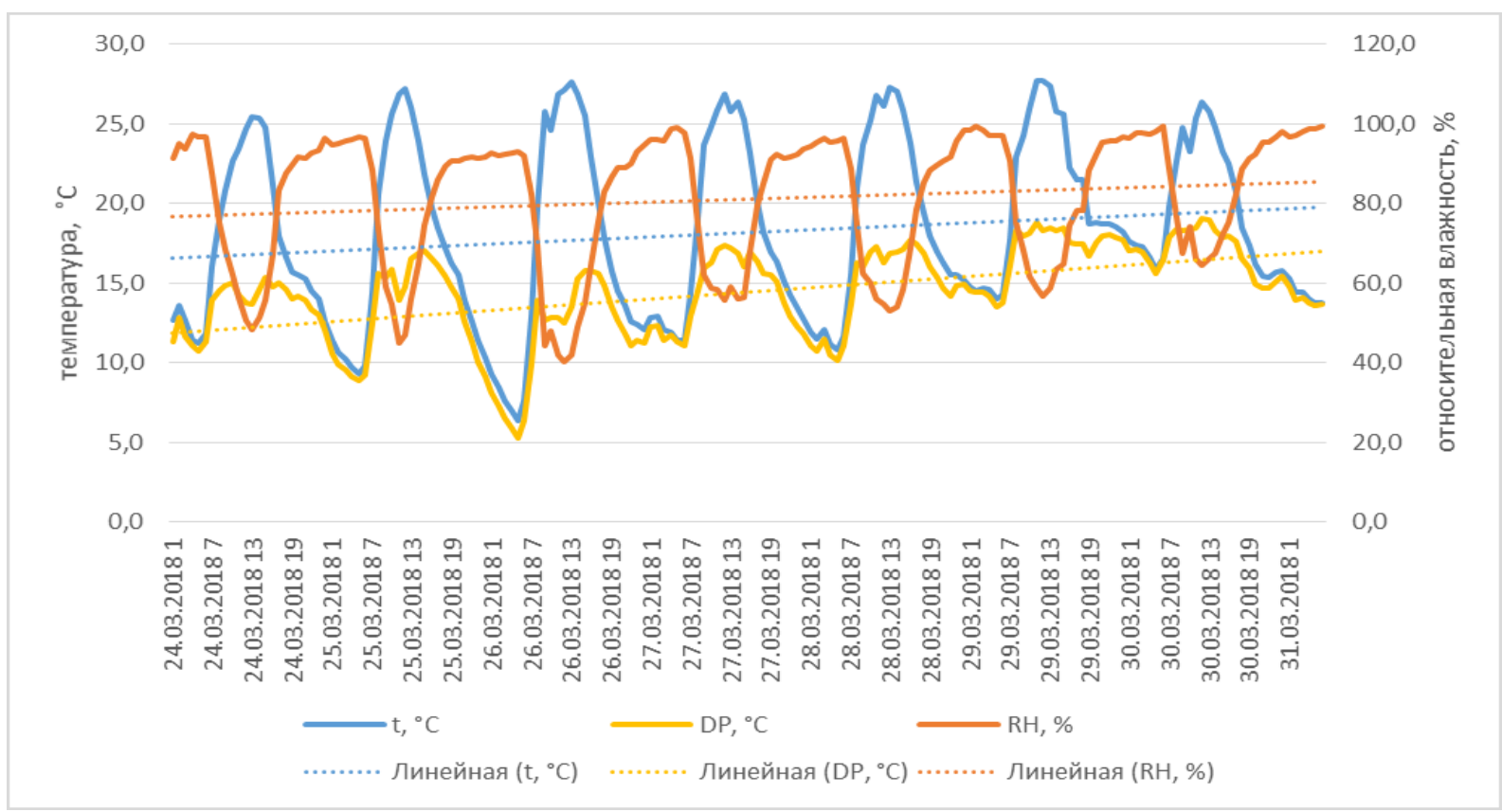

Рис. 5. Динамика температуры воздуха, точки росы и относительной влажности воздуха на лесном кордоне Зянг Ли

Прослеживается закономерное соотношение изменений температуры и относительной влажности воздуха - при понижении температуры воздуха относительная влажность возрастает. Кроме того, за период наблюдений фиксировалось постепенное повышение среднесуточной температуры воздуха с $17,7^{\circ} \mathrm{C}$ до $19,9^{\circ} \mathrm{C}$, что связано с заходом на территорию области пониженного давления, которая принесла более тёплые и влажные воздушные массы, и наблюдавшиеся в конце экспедиции атмосферные осадки. 


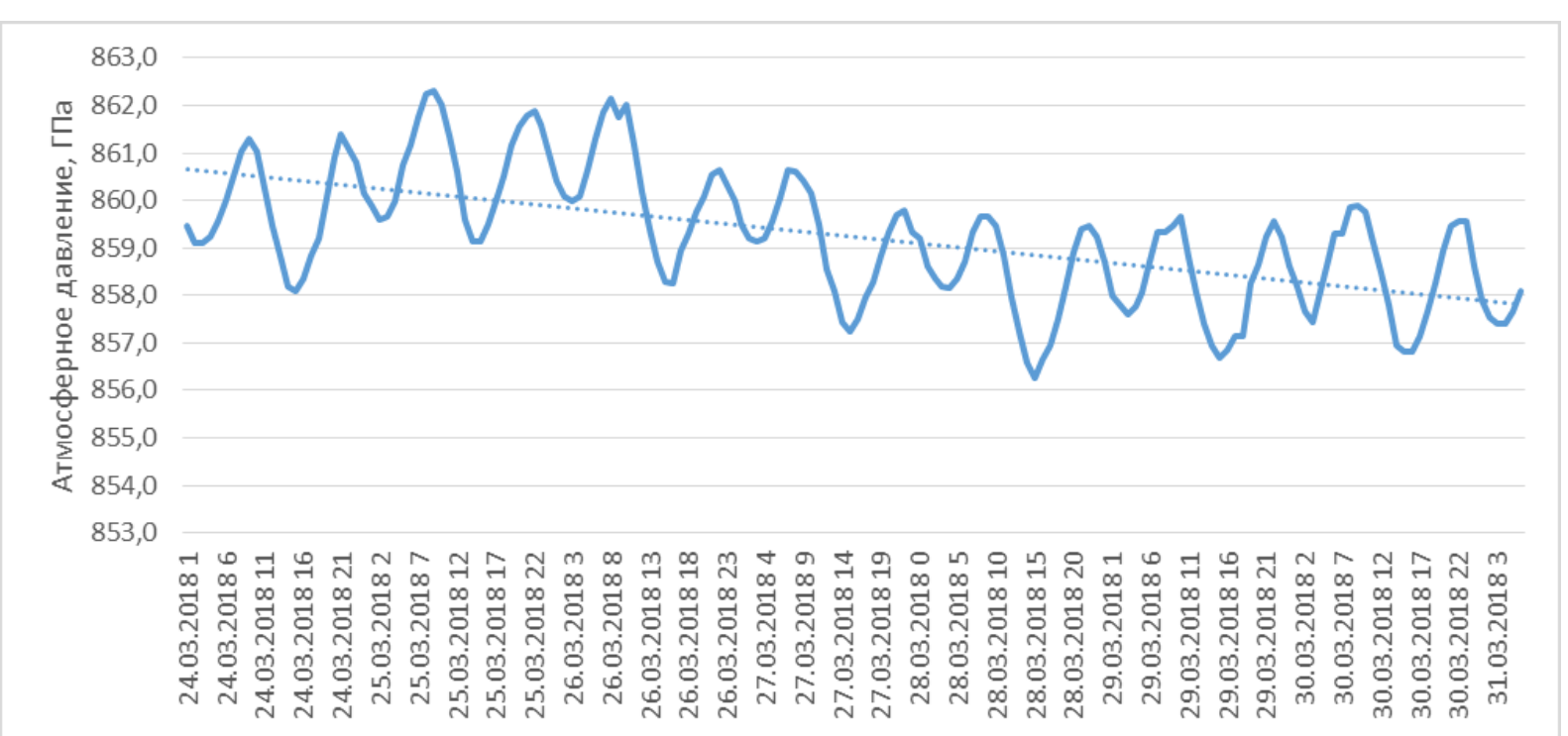

Рис. 6. Динамика атмосферного давления на лесном кордоне Зянг Ли

Суточный ход темпепратуры воздуха характеризуется значительными амплитудами. Максимум температуры воздуха наблюдался в полдень и достигал в среднем за период измерений $26,6^{\circ} \mathrm{C}$ (рис. 7). Минимальные значения характерны для периода утреннего выхолаживания и составили в среднем за наблюдаемый период 11,6 С. Таким образом, усредняя полученные ряды данных, можно говорить, что в конце сухого сезона суточная амплитуда температуры воздуха на изучаемой территории достигает $15{ }^{\circ} \mathrm{C}$. Вместе с тем, если брать экстремумы, то суточная амплитуда температуры может достигать более $20^{\circ} \mathrm{C}$.

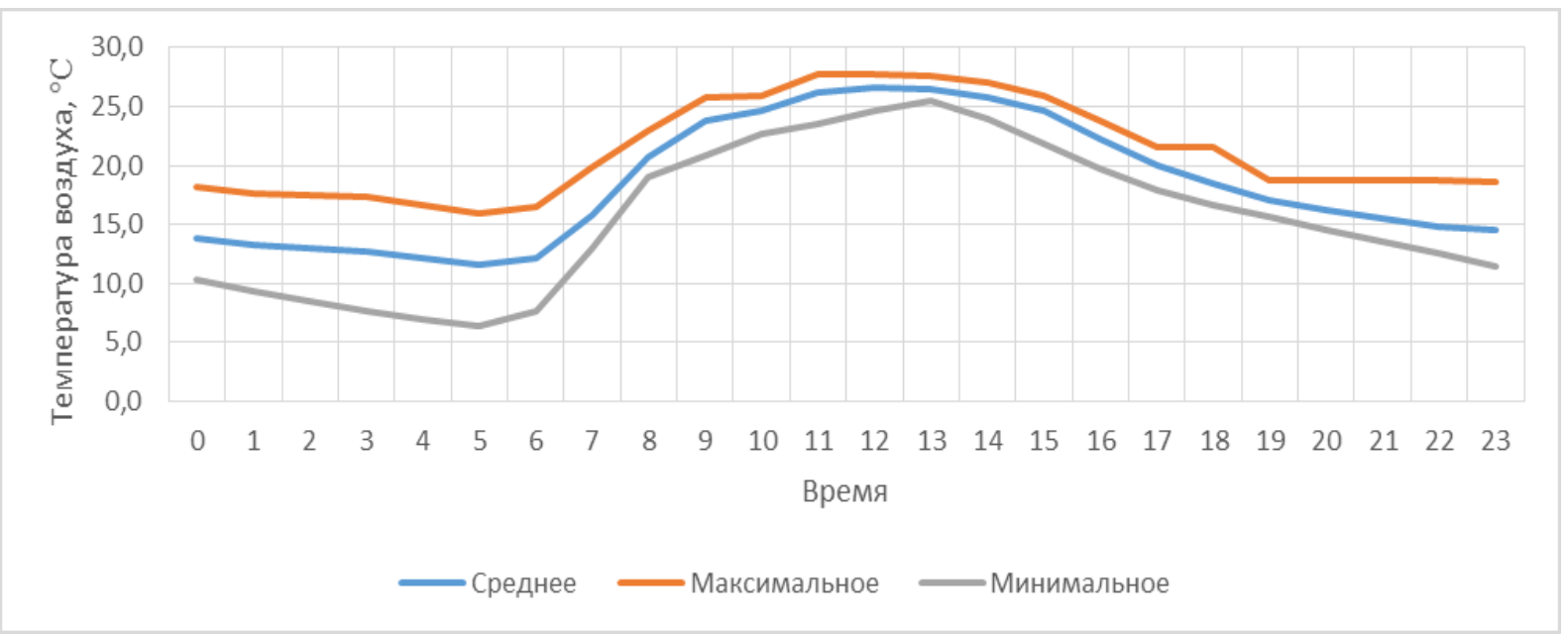

Рис. 7. Суточный ход температуры воздуха на лесном кордоне Зянг Ли

Из графика на рис. 7 следует, что наиболее вариативный период наблюдается во время утреннего выхолаживания, начинающегося около 4 утра и заканчивающегося около 6-7 часов утра. В этом периоде размах вариации достигает 9,7 ${ }^{\circ} \mathrm{C}$. Наиболее устойчивы температуры в 12.00-13.00. В этот период размах вариации составляет $2,2^{\circ} \mathrm{C}$.

Суточный ход влажности воздуха обратно пропорционален ходу температуры (рис. 8). Максимальные среднесуточные значения относительной влажности воздуха наблюдаются в ночные часы, и достигают более 95\%. В часы утреннего выхолаживания относительная влажность максимальна и составляет 96,9\%. Минимальные значения относительной влажности наблюдаются в полдень - 52,8\%. 


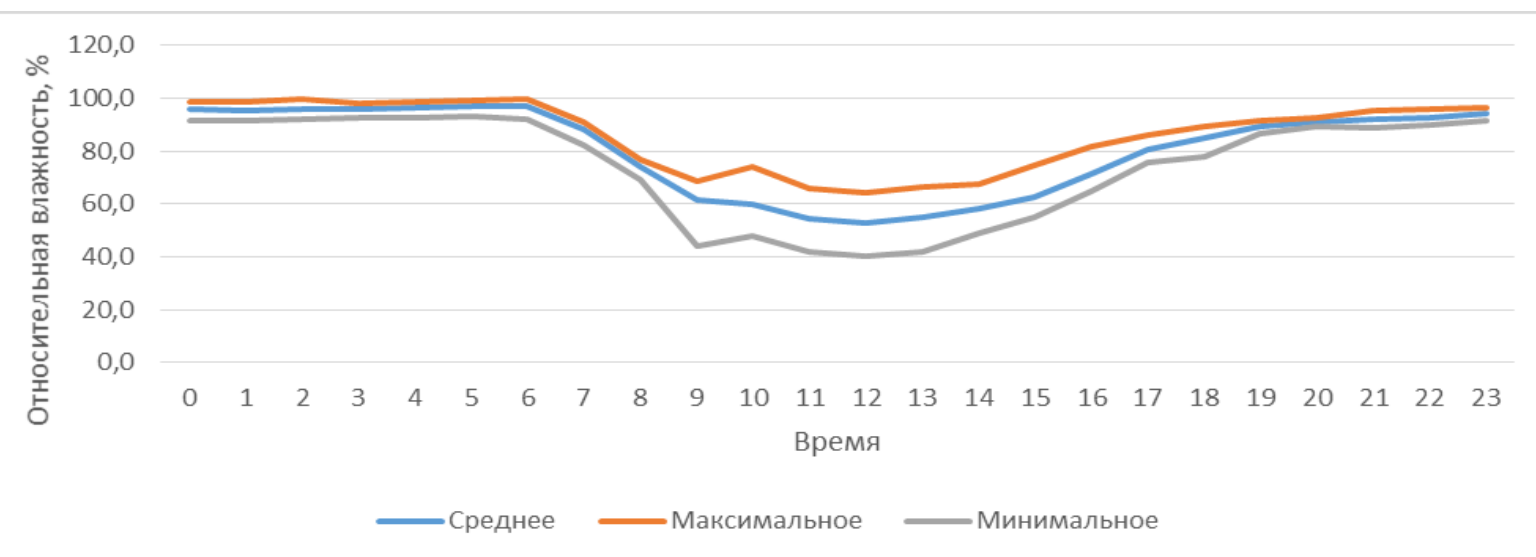

Рис. 8. Суточный ход относительной влажности воздуха на лесном кордоне Зянг Ли

Таким образом, суточная амплитуда относительной влажности воздуха в среднем составляет 44,1 \%. Если же брать экстремумы, то за наблюдаемый период суточная амплитуда колебалась от $35 \%$ до $52,8 \%$. Следует отметить, что наибольшим размахом вариации значения относительной влажности характеризуются дневные часы. Так, в полдень, размах вариации достигал $24,1 \%$. В часы утреннего выхолаживания $-6 \%$.

Описанная ситуация с температурой и относительной влажностью воздуха обнаруживает интересную зависимость, связанную с тем, что в часы утреннего выхолаживания наблюдаются наибольшие вариации значений температуры и наименьшие значения размаха вариации относительной влажности. То есть, в эти часы вне зависимости от температуры, влажность воздуха держится постоянно в пределах одинаково высоких значений. В это же время формируются туманы. Это видно на рис. 8 , где в ночные часы график хода относительной влажности находится на плато. В дневные же часы, наоборот, при достаточно постоянных значениях температуры наблюдается высокая вариабельность относительной влажности при её достаточно низких значениях.

Рост температуры воздуха и падение значений относительной влажности начинается в 6 утра с восходом солнца, когда практически всё количество поступающей солнечной радиации тратится на испарение туманов и росы. Этот процесс завершается в 9 утра и далее амплитуды суточного хода температуры и влажности воздуха выравниваются. Вечернее понижение температуры воздуха и повышение влажности воздуха начинается в 15.00 и происходит более равномерно, чем в утренние часы.

Почвенный покров исследованного участка представлен двумя типами почв: зональными желтозёмами (полевое диагностирование - жёлтые феррсиаллитные) и интразональными аллювиальными почвами в пойме реки и на острове.

Ферсиаллитные желтозёмы представлены подтипами желтозёмы типичные и лессивированные (Шишов и др., 1996). Желтозёмы формируются на делювии и пролювии магматических пород, а также на коре выветривания, которая, в пределах ключевого участка, развита слабо и редко достигает мощности 10 см, хотя в окрестностях стационара имеются разрезы, где мощность коры выветривания достигает более 10 м. В днищах ложбин в качестве почвообразующей породы выступает пролювий. Скелетность почвы возрастает вниз по профилю независимо от почвообразующих пород. Общий вид всех исследованных профилей ферсиаллитных желтозёмов представлен на сводном рис. 9.

На поверхности гребня структурной гряды под сосново-широколиственным лесом формируется маломощный легкосуглинистый желтозём типичный на глинистой коре выветривания дацитов. Общий вид профиля представлен на рис. 9а, описание разреза дано в таблице 2. 


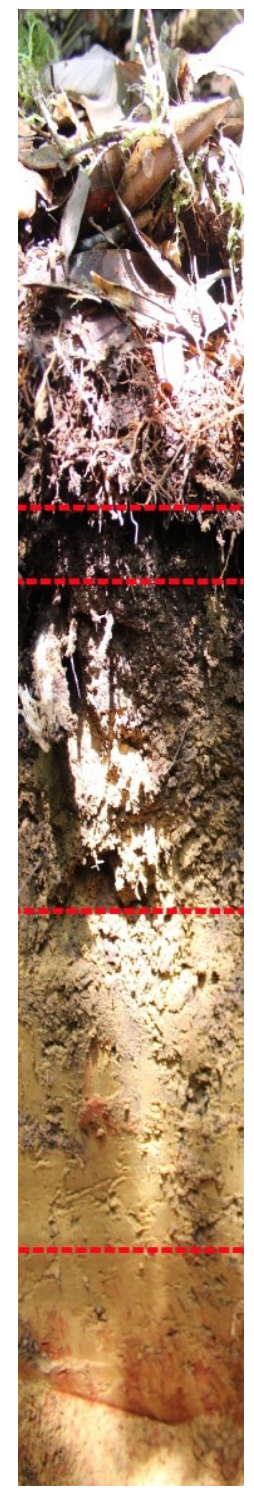

a)

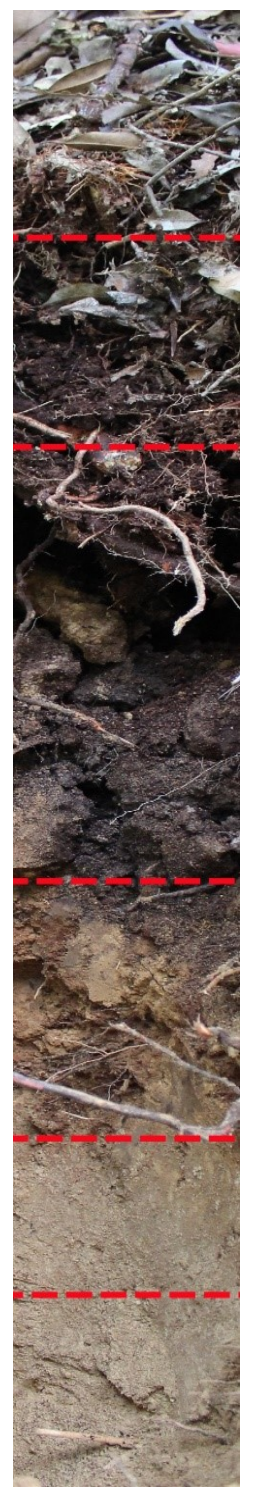

б)

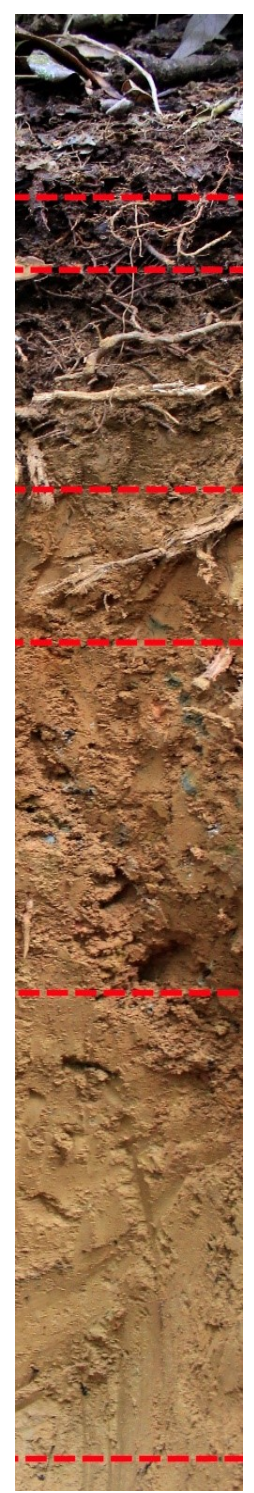

в)

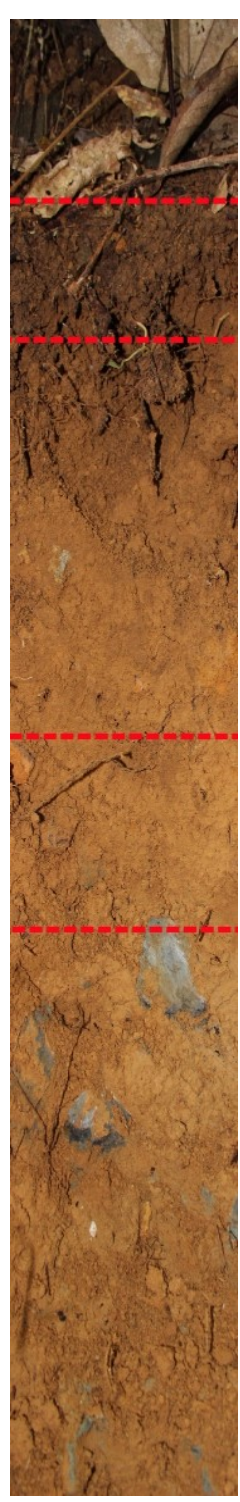

г)

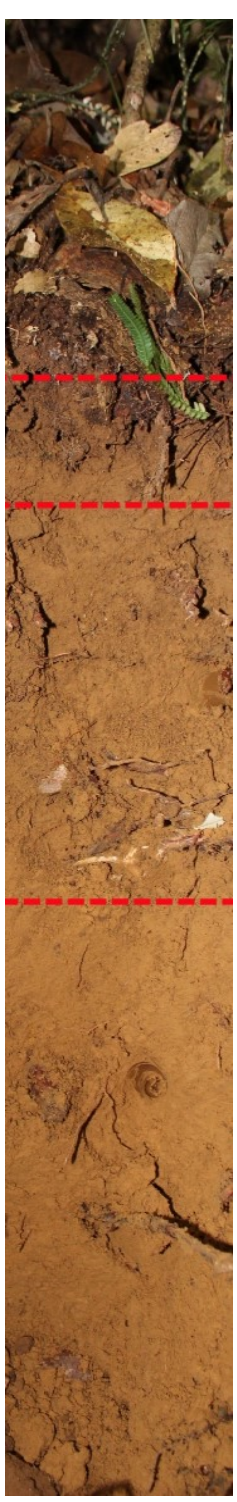

д)

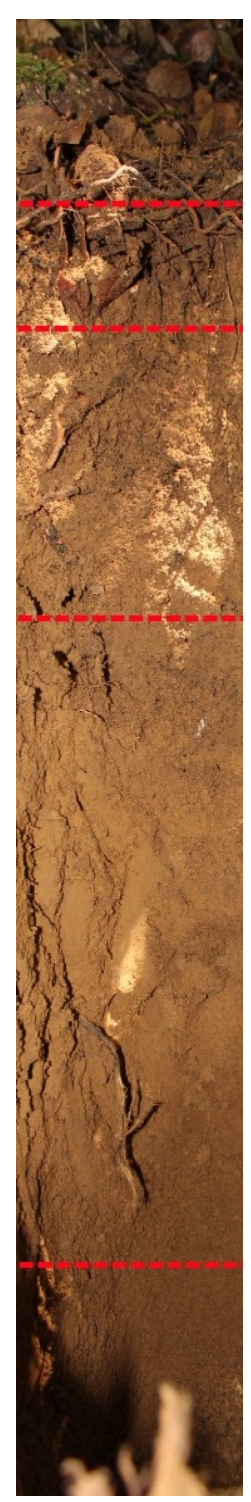

e)

Рис. 9. Общий вид описываемых разрезов: а) маломощный легкосуглинистый желтозём типичный на глинистой коре выветривания дацитов; б) среднемощный супесчаный желтозём лессивированный на щебнисто-каменном делювии дацитов; в) маломощный среднесуглинистый желтозём типичный на щебнисто-каменном делювии дацитов в средней части склона; г) маломощный среднесуглинистый желтозём типичный на щебнисто-каменном делювии дацитов в нижней части склона; д) маломощный среднесуглинистый желтозём типичный на щебнисто-каменном делювии дацитов на подножии склона; е) аллювиальная среднесуглинистая опесчаненная почва на галечниково-валунном аллювии дацитов, андезитов, туфов и песчаника. Красной штриховкой показаны границы почвенных горизонтов.

В верхней части склона структурной гряды на склонах северной экспозиции под среднесомкнутым широколиственным лесом с развитым травяным ярусом формируется среднемощный супесчаный желтозём лессивированный на щебнисто-каменном делювии дацитов. Микрорельеф почвенного покрова сформирован живыми и отмершими скелетными корнями деревьев. Мощность растительного опада составляет 15-20 см. Формирование опада и оторфованного горизонта связано с местоположением на холодном склоне северной экспозиции, где скорость биологического круговорота значительно ниже. Общий вид профиля представлен на рис. 9б, описание разреза приведено в таблице 3. 
Таблица 2.

Описание почвенного разреза маломощного легкосуглинистого желтозёма типичного на глинистой коре выветривания дацитов

\begin{tabular}{|c|c|l|}
\hline Горизонт & Глубина, см & \multicolumn{1}{|c|}{ Описание } \\
\hline $\mathrm{A}_{0}$ & $0-2$ & $\begin{array}{l}\text { Светло-серо-коричневая, свежая, рыхлая, новообразований нет, включения: } \\
\text { корни растений, опад, переход четкий по цвету, форма границы ровная }\end{array}$ \\
\hline $\mathrm{A}_{1}$ & $2-4$ & $\begin{array}{l}\text { Серо-коричневая, свежая, легкосуглинистая, мелкокомковатая, рыхлая, } \\
\text { новообразований нет, включения: корни растений, переход постепенный по } \\
\text { цвету, форма границы не ровная }\end{array}$ \\
\hline $\mathrm{AE}$ & $4-18$ & $\begin{array}{l}\text { Светло-коричневая, свежая, легкосуглинистая, пылеватая, плотная, } \\
\text { новообразований нет, включения: редкие корни растений, переход } \\
\text { постепенный по цвету, форма границы не ровная }\end{array}$ \\
\hline ЕВ & $18-40$ & $\begin{array}{l}\text { Коричнево-жёлтая, влажная, среднесуглинистая, мелкокомковатая, плотная, } \\
\text { новообразования: красные пятна, включения: редкие корни растений, } \\
\text { переход постепенный по цвету, форма границы неровная }\end{array}$ \\
\hline $\mathrm{B}$ & $40-48$ & $\begin{array}{l}\text { Красно-жёлтая, влажная, среднесуглинистая, мелкокомковатая, плотная, } \\
\text { новообразования: красные пятна, включения: нет }\end{array}$ \\
\hline
\end{tabular}

Таблица 3.

Описание почвенного разреза среднемощного супесчаного желтозёма лессивированного на щебнисто-каменном делювии дацитов

\begin{tabular}{|c|c|l|}
\hline Горизонт & Глубина, см & \multicolumn{1}{|c|}{ Описание } \\
\hline $\mathrm{A}_{0}$ & $0-3$ & Растительный опад: листья и ветки \\
\hline At & $3-18$ & $\begin{array}{l}\text { Tорфянистый, тёмно-коричневый, сухой, рыхлый, новообразования: нет, } \\
\text { включения: обильные корни растений, переход четкий по цвету, граница } \\
\text { неровная }\end{array}$ \\
\hline $\mathrm{AE}$ & $18-29$ & $\begin{array}{l}\text { Светло-серо-коричневый, свежий, супесь, крупноглыбистая, уплотненный, с } \\
\text { высокой межагрегатной пористостью, новообразования: нет, включения: } \\
\text { корни растений, переходрезкий по цвету, граница неровная }\end{array}$ \\
\hline $\mathrm{B}_{1}$ & $29-58$ & $\begin{array}{l}\text { Коричнево-желтый, влажный, супесь мелкокомковато-пылеватая, } \\
\text { новообразования: железомарганцевые конкреции, включения: корни } \\
\text { растений, переход слабовыраженный по цвету, форма границы ровная }\end{array}$ \\
\hline $\mathrm{B}_{2}$ & $58-82$ & $\begin{array}{l}\text { Коричнево-желтый, влажный, супесь, мелкокомковато-пылеватый, } \\
\text { новообразования: нет, включения: корни растений, переход постепенный по } \\
\text { цвету, форма границы ровная }\end{array}$ \\
\hline $\mathrm{B}_{3}$ & $82-96$ & $\begin{array}{l}\text { Палево-желтый, влажный, песок, комковатая, новообразования: } \\
\text { железомарганцевые пленки, включения: корни растений }\end{array}$ \\
\hline
\end{tabular}

В средней части склона структурной гряды под среднесомкнутым широколиственным лесом с тремя древесными подъярусами (при этом нижний фрагментарен) и с хорошо развитым травяным ярусом формируется маломощный среднесуглинистый желтозём типичный на щебнисто-каменном делювии дацитов. Общий вид профиля представлен на рис. 9в, описание разреза дано в таблице 4.

В нижней части и на подошве склона под широколиственным лесом с тремя древесными подъярусами (нижний из которых разрежен) и фрагментарным травяным ярусом происходит упрощение профиля желтозёма, нетипичное снижение его мощности (рис. 9Г-д, табл. 5, 6), что свидетельствует о низкой интенсивности склонового перемещения материала.

Не исключено, что наблюдаемые угловатые обломки горной породы, принятые нами за делювиальные отложения в средней части склона, являются элювием.

На территории острова в русле реки под пойменным широколиственным лесом формируется маломощная аллювиальная среднесуглинистая почва на песчаном и галечниково-валунном аллювии дацитов, андезитов, туфов и песчаника. Общий вид профиля представлен на рис. 9е, описание разреза дано в таблице 7. 
Таблица 4.

Описание почвенного разреза маломощного среднесуглинистого желтозёма типичного на щебнисто-каменном делювии дацитов в средней части склона

\begin{tabular}{|c|c|c|}
\hline Горизонт & Глубина, см & Описание \\
\hline $\mathrm{A}_{0}$ & $0-3$ & Растительный опад: листья и ветки \\
\hline A & $3-8$ & $\begin{array}{l}\text { Коричневая, влажная, среднесуглинистая, мелкокомковатая, рыхлая, } \\
\text { новообразования: нет, включения: обильные корни растений, переход чёткий } \\
\text { по цвету, форма границы неровная }\end{array}$ \\
\hline $\mathrm{AB}$ & $8-22$ & $\begin{array}{l}\text { Серо-коричневая, влажная, легкосуглинистая, мелкокомковатая, } \\
\text { уплотнённая, новообразования: нет, включения: корни растений, щебень } \\
\text { дацита, переход постепенный по цвету, форма границы ровная }\end{array}$ \\
\hline $\mathrm{B}_{1}$ & $22-32$ & $\begin{array}{l}\text { Светло-коричневая, влажная, среднесуглинистая, комковатая, плотная, } \\
\text { новообразования: железомарганцевые конкреции, включения: корни } \\
\text { растений, камни и щебень дацита, переход нечёткий по цвету, форма } \\
\text { границы ровная }\end{array}$ \\
\hline $\mathrm{B}_{2}$ & $32-59$ & $\begin{array}{l}\text { Коричнево-жёлтая, влажная, легкосуглинистая, комковатая, плотная, } \\
\text { новообразования: железомарганцевые конкреции (более обильно), } \\
\text { включения: корни растений, камни и щебень дацита, переход резкий по } \\
\text { цвету, форма границы ровная }\end{array}$ \\
\hline $\mathrm{B}_{3}$ & $59-112$ & $\begin{array}{l}\text { Палево-коричневая, влажная, легкосуглинистая, мелкокомковатая, плотная, } \\
\text { новообразования: железомарганцевые конкреции, включения: сильно } \\
\text { выветрелые камни и щебень дацита, переход резкий по включениям, форма } \\
\text { границы ровная }\end{array}$ \\
\hline $\mathrm{BC}$ & более 112 & Делювий дацитов \\
\hline
\end{tabular}

Таблица 5.

Описание почвенного разреза маломощного среднесуглинистого желтозёма типичного на щебнисто-каменном делювии дацитов в нижней части склона

\begin{tabular}{|c|c|l|}
\hline Горизонт & Глубина, см & \multicolumn{1}{|c|}{ Описание } \\
\hline $\mathrm{A}_{0}$ & $0-1$ & \multicolumn{1}{|c|}{ Растительный опад: листья и ветки } \\
\hline А & $1-8$ & $\begin{array}{l}\text { Серо-коричнево-желтая, влажная, легкосуглинистая, мелкокомковатая, } \\
\text { рыхлая, новообразования: нет, включения: корни растений, переход } \\
\text { постепенный по цвету, форма границы ровная }\end{array}$ \\
\hline АВ & $8-26$ & $\begin{array}{l}\text { Жёлто-коричневая, влажная, среднесуглинистая, мелкокомковатая, } \\
\text { уплотнённая, новообразования: нет, включения: корни растений, щебень } \\
\text { дацита, переход постепенный по цвету, форма границы ровная }\end{array}$ \\
\hline В & $26-37$ & $\begin{array}{l}\text { Жёлто-светло-коричневая, влажная влажная, среднесуглинистая, } \\
\text { мелкокомковатая, уплотнённая, новообразования: нет, включения: корни } \\
\text { растений, камни и щебень дацита, переход резкий по включения, форма } \\
\text { границы неровная }\end{array}$ \\
\hline ВС & $37-65$ & $\begin{array}{l}\text { Жёлто-светло-коричневая, влажная, легкосуглинистая, мелкокомковатая, } \\
\text { новообразования: нет, включения: корни растений, камни и щебень дацита } \\
\text { (до 90\%) }\end{array}$ \\
\hline
\end{tabular}

Таблица 6.

Описание почвенного разреза маломощного среднесуглинистого желтозёма типичного на щебнисто-каменном делювии дацитов на подножии склона

\begin{tabular}{|c|c|l|}
\hline Горизонт & Глубина, см & \multicolumn{1}{|c|}{ Описание } \\
\hline $\mathrm{A}_{0}$ & $0-3$ & Растительный опад: листья и ветки \\
\hline $\mathrm{A}$ & $3-8$ & $\begin{array}{l}\text { Тёмно-серо-коричневая, свежая, легкосуглинистая, комковатая, рыхлая, } \\
\text { новообразования: нет, включения: корни растений, переход постепенный по } \\
\text { цвету, форма границы ровная }\end{array}$ \\
\hline $\mathrm{AB}$ & $8-26$ & $\begin{array}{l}\text { Светло-серо-коричневая, свежая, среднесуглинистая, комковатая, } \\
\text { уплотнённая, новообразования: нет, включения: корни растений, переход } \\
\text { постепенный по цвету и плотности, форма границы ровная }\end{array}$ \\
\hline $\mathrm{B}$ & $26-56$ & $\begin{array}{l}\text { Светло-коричневая, влажная, среднесуглинистая, комковатая, уплотнённая, } \\
\text { новообразования: нет, включения: корни растений }\end{array}$ \\
\hline
\end{tabular}




\section{Таблица 7.}

Описание почвенного разреза аллювиальная среднесуглинистая опесчаненная почва на галечниково-валунном аллювии дацитов, андезитов, туфов и песчаника

\begin{tabular}{|c|c|l|}
\hline Горизонт & Глубина, см & \multicolumn{1}{|c|}{ Описание } \\
\hline $\mathrm{A}_{0}$ & $0-1$ & Растительный опад: листья и ветки \\
\hline $\mathrm{AB}$ & $1-8$ & $\begin{array}{l}\text { Серо-коричневая, свежая, легкосуглинистая слабоопесчаненная, } \\
\text { мелкокомковатая, рыхлая, новообразования: нет, включения: корни растений, } \\
\text { детрит, переход нечёткий постепенный по плотности и механическому } \\
\text { составу, форма границы ровная }\end{array}$ \\
\hline $\mathrm{B}_{1}$ & $8-22$ & $\begin{array}{l}\text { Серо-коричневая, влажная, среднесуглинистая опесчаненная, } \\
\text { крупнокомковатая, уплотненная, новообразования: нет, включения: корни } \\
\text { растений, переход нечёткий постепенный по плотности и механическому } \\
\text { составу, форма границы ровная }\end{array}$ \\
\hline $\mathrm{B}_{2}$ & $22-63$ & $\begin{array}{l}\text { Серо-коричневая, мокрая, песчаная, мелкозернистая, плотная, включения: } \\
\text { галька и гравий аллювия, переход резкий по включениям, форма границы } \\
\text { ровная }\end{array}$ \\
\hline $\mathrm{BC}$ & $63-71$ & $\begin{array}{l}\text { Серо-коричневая, мокрая, песчаная, мелкозернистая, плотная, включения: } \\
\text { обильная галька и гравий аллювия }\end{array}$ \\
\hline
\end{tabular}

Из каждого горизонта выявленных и описанных на стационаре двух основных зональных подтипов почв - желтозёма типичного и желтозёма лессивированного были отобраны пробы для проведения последующих лабораторных физико-химических исследований. Пробы были переданы в Институт Географических экспериментальных исследований Академии наук и технологий Вьетнама, где выполнялись определения основных показателей и общего химического состава почвенных образцов. Результаты выполненных определений приведены в таблицах 8 и 9.

Изучению геохимии почв Вьетнама посвящены работы В.О. Лопес де Гереню с соавторами (2011, 2015), А.А. Околеловой, Тхинь Нгуен Ван, В.К. Авилова (2014), О.С. Хохловой с соавторами (2017). В работах детально описаны суточная и сезонная динамика потока $\mathrm{CO}_{2}$ из почв в различных древостоях муссонного тропического леса, факторы неоднородности этого процесса, свойства и морфогенетические особенности основных типов почв Южного Вьетнама (заповедник Донгнай, национальный парк Каттьен). Однако описанные в этих работах почвы формируются в равнинных условиях юга Вьетнама. Горные же почвы Южного Вьетнама остаются на сегодняшний день практически не изученными.

В ходе полевого диагностирования наблюдаемые почвы отнесены к желтым феррсиаллитным почвам в соответствии с классификацией, предложенной (Шишов и др, 1996) по характеру дифференциации профиля и цвету горизонтов. Геохимическое опробование подтвердило предположение по соотношению валового состава силикатов и полуторных оксидов. Однако почвы характеризуются высокими концентрациями органического углерода и азота, более характерным для темно-красных ферралитных почв. Кроме того, значитальна доля илистых частиц, что характерно для красных ферралитных почв. Точное диагностирование почв является предметом дальнейшего делального исследования.

Анализ данных физико-химического исследования образцов горизонтов желтозёма типичного среднесуглинистого позволяет получить представление об общем химическом составе почвы, уточнить распределение химических элементов по почвенному профилю и вынести суждения о возможном наличии закономерностей такого распределения. Физические свойства почв, такие, как размер и соотношение почвенных фракций, самым непосредственным образом влияют на почвенные процессы и химический состав. Соотношение тонкопесчаных, пылеватых и глинистых частиц по горизонтам соответствует их закономерному распределению по почвенному профилю: содержание тонкопесчаных частиц уменьшается к иллювиальному и минеральному горизонтам, в то время, как содержание пылеватых частиц достигает своего максимального значения в минеральном, а глинистых частиц - в иллювиальном горизонтах соответственно. 
Таблица 8.

Результаты аналитических исследований среднесуглинистого желтозёма типичного на щебнисто-каменном делювии дацитов

\begin{tabular}{|c|c|c|c|c|c|c|c|c|c|}
\hline \multirow{2}{*}{ № п/п } & \multirow{2}{*}{ Параметр } & \multirow{2}{*}{ Единица измерения } & \multirow{2}{*}{ Метод } & \multicolumn{6}{|c|}{ Горизонты } \\
\hline & & & & $\mathrm{A}$ & $\mathrm{AB}$ & $\mathrm{B}_{1}$ & $\mathrm{~B}_{2}$ & $\mathrm{BC}$ & $\mathrm{C}$ \\
\hline 1 & $\mathrm{pH}_{\mathrm{KCl}}$ & - & TCVN 5979:1995 & 3,77 & 3,94 & 4,09 & 4,16 & 3,96 & 3,97 \\
\hline 2 & Содержание органического углерода & $\%$ & TCVN 9294:2012 & 10,650 & 7,906 & 1,543 & 0,482 & 0,377 & 0,238 \\
\hline \multirow{3}{*}{3} & \multirow{3}{*}{ Классы размера частиц } & $0,2-0,02$ мм, \% & \multirow{3}{*}{ TCVN6862:2012 } & 47,00 & 41,84 & 29,74 & 35,06 & 43,92 & 36,04 \\
\hline & & $0,02-0,002 \mathrm{мM}, \%$ & & 34,36 & 39,60 & 33,14 & 40,46 & 38,66 & 46,94 \\
\hline & & $<0,002$ мM, $\%$ & & 18,64 & 18,56 & 37,12 & 24,48 & 17,42 & 17,02 \\
\hline 4 & Ёмкость катионного обмена & МГ-ЭКВ/100 Г & TCVN 8568:2010 & 24,05 & 15,35 & 12,00 & 9,40 & 10,75 & 11,75 \\
\hline 5 & $\mathrm{Ca}^{2+}$ & мг-эКв/100 г & \multirow{4}{*}{ TCVN 8569:2010 } & 1,103 & 1,243 & 1,689 & 1,168 & 0,677 & 0,470 \\
\hline 6 & $\mathrm{Mg}^{2+}$ & МГ-ЭКв/100 г & & 0,956 & 0,492 & 0,313 & 0,205 & 0,271 & 0,243 \\
\hline 7 & $\mathrm{~K}^{+}$ & МГ-ЭКВ/100 Г & & 0,453 & 0,305 & 0,093 & 0,070 & 0,088 & 0,075 \\
\hline 8 & $\mathrm{Na}^{+}$ & МГ-ЭКВ/100 г & & 0,318 & 0,397 & 0,409 & 0,306 & 0,261 & 0,255 \\
\hline 9 & $\mathrm{Al}^{3+}$ & МГ-ЭКВ/100 Г & \multirow{3}{*}{ TCVN 4403:2011 } & 0,00 & 0,00 & 1,65 & 0,70 & 2,60 & 2,50 \\
\hline 10 & $\mathrm{H}^{+}$ & МГ-ЭКв/100 г & & 3,75 & 3,00 & 0,70 & 0,85 & 0,90 & 0,75 \\
\hline 11 & Обменная кислотность & МГ-эКв/100 Г & & 3,75 & 3,00 & 2,35 & 1,55 & 3,50 & 3,25 \\
\hline 12 & Общий Si & $\% \mathrm{SiO}_{2}$ & TCVN 7891:2008 & 34,98 & 81,70 & 46,37 & 40,98 & 48,85 & 49,66 \\
\hline 13 & Общий Al & $\% \mathrm{Al}$ & \multirow{8}{*}{ TCVN6496:1999-ICPMS } & 6,1636 & 7,3822 & 5,6776 & 7,6029 & 5,0139 & 5,7273 \\
\hline 14 & Общий $\mathrm{Fe}$ & $\% \mathrm{Fe}$ & & 5,1127 & 5,7030 & 4,8858 & 5,4155 & 4,9312 & 4,3930 \\
\hline 15 & Общий Сa & $\mathrm{мгCa/ \kappa г}$ & & 427,41 & 401,34 & 402,67 & 1047,28 & 220,87 & 360,95 \\
\hline 16 & Общий $\mathrm{Mg}$ & $\mathrm{M \Gamma Mg/Кг}$ & & 2170,37 & 1911,56 & 1698,06 & 2319,23 & 4244,29 & 2024,41 \\
\hline 17 & Общий K & $\mathrm{M \Gamma K} / \mathrm{K \Gamma}$ & & 728,75 & 695,45 & 431,43 & 789,32 & 1978,52 & 873,04 \\
\hline 18 & Общий $\mathrm{Na}$ & $\mathrm{M} \Gamma \mathrm{Na} / \mathrm{\kappa} \Gamma$ & & 191,18 & 176,79 & 137,29 & 174,24 & 150,91 & 163,19 \\
\hline 19 & Общий Тi & мГТі/кг & & 1606,14 & 1592,77 & 1456,35 & 1065,71 & 1105,27 & 737,51 \\
\hline 20 & Общий Mn & МгMn/кг & & 434,19 & 453,46 & 347,76 & 482,53 & 383,77 & 304,88 \\
\hline 21 & Общий P & $\% \mathrm{P}_{2} \mathrm{O}_{5}$ & TCVN 8940:2011 & 0,168 & 0,164 & 0,126 & 0,167 & 0,243 & 0,137 \\
\hline 22 & Общий N & $\% \mathrm{~N}$ & TCVN 6498:1999 & 0,701 & 0,434 & 0,099 & 0,031 & 0,023 & 0,023 \\
\hline 23 & Активный Р & $\mathrm{M \Gamma}_{2} \mathrm{O}_{5} / 100 \Gamma$ & TCVN 5256:2009 & 14,839 & 30,028 & 15,137 & 14,785 & 15,283 & 14,785 \\
\hline 24 & Активный K & $\mathrm{M \Gamma} / 100 \Gamma$ & TCVN 8662:2011 & 9,811 & 6,991 & 1,788 & 1,722 & 1,778 & 2,088 \\
\hline
\end{tabular}


Результаты аналитических исследований среднемощного супесчаного желтозёма лессивированного

Таблица 9. на щебнисто-каменном делювии дацитов

\begin{tabular}{|c|c|c|c|c|c|c|c|}
\hline \multirow{2}{*}{ № ח/п } & \multirow{2}{*}{ Параметр } & \multirow{2}{*}{ Единица измерения } & \multirow{2}{*}{ Метод } & \multicolumn{4}{|c|}{ Горизонты } \\
\hline & & & & $\mathrm{AE}$ & $\mathrm{B}_{1}$ & $\mathrm{~B}_{2}$ & $\mathrm{~B}_{3}$ \\
\hline 1 & $\mathrm{pH}_{\mathrm{KCl}}$ & - & TCVN 5979:1995 & 2,11 & 3,72 & 3,92 & 3,87 \\
\hline 2 & Содержание органического углерода & $\%$ & TCVN 9294:2012 & 59,695 & 2,995 & 2,787 & 0,758 \\
\hline \multirow{3}{*}{3} & \multirow{3}{*}{ Классы размера частиц } & $0,2-0,02$ мM, $\%$ & \multirow{3}{*}{ TCVN6862:2012 } & 94,33 & 54,18 & 64,74 & 66,48 \\
\hline & & $0,02-0,002$ мм, $\%$ & & 1,31 & 22,84 & 17,14 & 21,58 \\
\hline & & $<0,002$ мм, $\%$ & & 4,36 & 22,98 & 18,12 & 11,94 \\
\hline 4 & Ёмкость катионного обмена & МГ-ЭКВ/100 г & TCVN 8568:2010 & 43,90 & 21,90 & 16,25 & 7,50 \\
\hline 5 & $\mathrm{Ca}^{2+}$ & Мг-эКв/100 г & \multirow{4}{*}{ TCVN 8569:2010 } & 0,705 & 0,429 & 0,425 & 0,853 \\
\hline 6 & $\mathrm{Mg}^{2+}$ & мГ-ЭКВ/100 г & & 1,755 & 0,103 & 0,072 & 0,147 \\
\hline 7 & $\mathrm{~K}^{+}$ & МГ-эКВ/100 Г & & 0,624 & 0,061 & 0,042 & 0,055 \\
\hline 8 & $\mathrm{Na}^{+}$ & МГ-ЭКВ/100 Г & & 0,717 & 0,158 & 0,141 & 0,201 \\
\hline 9 & $\mathrm{Al}^{3+}$ & МГ-ЭКВ/100 г & \multirow{3}{*}{ TCVN 4403:2011 } & 0,00 & 8,50 & 4,40 & 3,20 \\
\hline 10 & $\mathrm{H}^{+}$ & МГ-ЭКВ/100 Г & & 14,00 & 1,45 & 1,05 & 0,80 \\
\hline 11 & Обменная кислотность & мГ-экв/100 г & & 14,00 & 9,95 & 5,45 & 4,00 \\
\hline 12 & Общий Si & $\% \mathrm{SiO}_{2}$ & TCVN 7891:2008 & 7,40 & 28,03 & 74,56 & 78,14 \\
\hline 13 & Общий $\mathrm{Al}$ & $\% \mathrm{Al}$ & \multirow{8}{*}{ TCVN6496:1999-ICPMS } & 0,2235 & 1,7611 & 2,5169 & 2,715 \\
\hline 14 & Общий Fe & $\% \mathrm{Fe}$ & & 0,0678 & 0,7813 & 0,6595 & 0,4984 \\
\hline 15 & Общий Сa & мгСа/кг & & 252,66 & 250,42 & 248,70 & 275,50 \\
\hline 16 & Общий $\mathrm{Mg}$ & МгMg/Кг & & 279,19 & 169,26 & 175,00 & 161,27 \\
\hline 17 & Общий K & мГК/Кг & & 219,58 & 374,85 & 625,23 & 960,56 \\
\hline 18 & Общий $\mathrm{Na}$ & 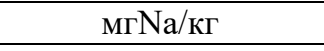 & & 1357,26 & 125,54 & 129,21 & 340,00 \\
\hline 19 & Общий Тi & мГТі/кг & & 8,58 & 3,78 & 3,66 & 6,71 \\
\hline 20 & Общий Mn & $\mathrm{M \Gamma Mn/ \kappa \Gamma}$ & & 6,45 & 18,76 & 16,77 & 17,92 \\
\hline 21 & Общий P & $\% \mathrm{P}_{2} \mathrm{O}_{5}$ & TCVN 8940:2011 & 0,105 & 0,036 & 0,044 & 0,043 \\
\hline 22 & Общий N & $\% \mathrm{~N}$ & TCVN 6498:1999 & 1,783 & 0,128 & 0,104 & 0,032 \\
\hline 23 & Активный Р & $\mathrm{M \Gamma P}_{2} \mathrm{O}_{5} / 100 \Gamma$ & TCVN 5256:2009 & 14,596 & 14,888 & 16,625 & 16,975 \\
\hline 24 & Активный K & Мг/100 г & TCVN 8662:2011 & 18,865 & 3,446 & 2,107 & 1,814 \\
\hline
\end{tabular}


Значение обменного $\mathrm{pH}_{\mathrm{KCl}}$ почвенной вытяжки указывает на тенденцию снижения кислотности от гумусового к минеральному горизонту. Аналогично уменьшается содержание органического углерода в почве с максимальными значениями в гумусовом и переходном (AB) горизонтах, и его резкое (от 7,9 до 1,5\%) снижение уже в иллювиальном горизонте В1. Обменная кислотность (мг-экв/100г), рассчитанная по вытяжке ионов водорода и алюминия, уменьшается к иллювиальным горизонтам и имеет два пика - в гумусовом и минеральном горизонтах.

Обменная кислотность в гумусовом горизонте обусловлена присутствием иона водорода, в то время, как в минеральном горизонте - ионами алюминия; вместе с тем, ионы алюминия появляются в иллювиальном горизонте $\mathrm{B}_{1}$. Подобное распределение коррелирует с содержанием и распределением по горизонтам оксидов кремния, алюмосиликатов и гидроксидов железа, общий процент содержания которых во всех минеральных горизонтах не ниже $50 \%$, с максимумом в переходном горизонте АВ (свыше 90 \%) и последующее уменьшение с глубиной, а минимальное содержание - в гумусовом горизонте А (45 \%).

Емкость катионного обмена значительно уменьшается к иллювиальному горизонту $\mathrm{B}_{2}$, и немного увеличивается к минеральному горизонту С. При этом содержание обменных катионов распределяется либо так же - уменьшается к иллювиальному горизонту $\mathrm{B}_{2}$, и немного увеличивается к минеральному горизонту С $\left(\mathrm{Mg}^{2+}\right.$ и $\left.\mathrm{K}^{+}\right)$, либо имеет пик накопления $\left(\mathrm{Ca}^{2+}\right.$ и $\left.\mathrm{Na}^{+}\right)$в иллювиальном горизонте $\mathrm{B}_{1} \mathrm{c}$ последующим уменьшением к минеральному горизонту С. Поглотительная способность почвы, вслед за содержанием иона водорода, уменьшается к минеральным горизонтам, насыщенность почв основаниями уменьшается от $50 \%$ до $30 \%$.

Общее содержание доступных для растений биогенных элементов - фосфора $\left(\mathrm{P}_{2} \mathrm{O}_{5}, \%\right.$ и мг $\mathrm{P}_{2} \mathrm{O}_{5} / 100$ г) и азота $(\mathrm{N}, \%)$, активного К и других - определяет биологическую ценность почв. Содержание фосфора (\%) уменьшается от гумусового к иллювиальному горизонту, а в пересчете на мг/100 г, среднее значение по горизонтам составляет 14-15 мг/100 г, пик аккумуляции приходится на горизонт $\mathrm{AB}-30$ мг/100 г. Содержание азота (\%) закономерно уменьшается (вслед за содержанием органического углерода) от гумусового (А) к минеральному горизонту (C).

$\mathrm{Si}, \mathrm{Al}, \mathrm{Fe}, \mathrm{Ca}, \mathrm{Na}, \mathrm{K}, \mathrm{Mg}, \mathrm{Ti}, \mathrm{Mn}$ - относятся к элементам с высоким кларком концентрации в земной коре и имеют соответствующий ряд распределения. Следовательно, общее содержание элементов, не соответствующее данному распределению, будет указывать на геохимические особенности отдельных типов почв. Полученные данные свидетельствуют о том, что содержание в желтозёме $\mathrm{K}, \mathrm{Mg}$, Ti и $\mathrm{Mn}$ значительно превышают содержание в почве Са и $\mathrm{Na}$. Нa $\mathrm{Mg}$ и Ті приходятся самые высокие значения - 4244,29 мг Mg/кг для иллювиального горизонта ВС и 1606,14 мгТі/кг для гумусового горизонта А. Содержание титана постепенно уменьшается с глубиной, а его высокое содержание в почве (наряду с $\mathrm{K}, \mathrm{Mg}$ и $\mathrm{Mn}$ ) обусловливается химическим составом почвообразующих пород.

$\mathrm{Ca}, \mathrm{Na}$ и $\mathrm{Mn}$ имеют схожую миграцию по профилю, и два максимума аккумуляции - в гумусовом горизонте А и в иллювиальном горизонте $\mathrm{B}_{2}$. Такое распределение может быть связано с образованием геохимической ловушки в горизонте $\mathrm{B}_{2}$, всвязи с уменьшением кислотности почвенной среды, так как Са и $\mathrm{Na}$ (наряду с $\mathrm{Mg}$ ) относится к элементам водной миграции. В частности, содержание $\mathrm{Mg}$ и К также уменьшается к минеральным горизонтам, но имеют другие максимумы аккумуляции - в гумусовом горизонте А и в минеральном горизонте ВС. Не исключено, что аккумуляция К в горизонте ВС связана с увеличением плотности (увеличение содержания пылеватых и глинистых частиц) в нижележащем горизонте С.

Соотношение тонкопесчаных, пылеватых и глинистых частиц по горизонтам в супесчаном лессивированном желтозёме существенно отличается от их распределения 
по почвенному профилю в описанном выше желтозёме типичном среднесуглинистом: содержание тонкопесчаных частиц постепенно увеличивается с максимумом в минеральном горизонте, в то время, как содержание пылеватых частиц достигает своего максимального значения в гумусовом, а глинистых частиц - в иллювиальном горизонте соответственно.

Значение обменного $\mathrm{pH}_{\mathrm{KCl}}$ почвенной вытяжки почти не изменяется, становится чуть более щелочной. Вместе с тем, содержание органического углерода в почве уменьшается значительно от гумусового $(10,65$ \%) к иллювиальному горизонту В 1 $(2,995 \%)$. Обменная кислотность (мг-экв/100 г), рассчитанная по вытяжке ионов водорода и алюминия, уменьшается в иллювиальном горизонте $(9,95$ мг-экв/100 г), в то время, как гумусовом горизонте отмечается минимум (3,75 мг-экв/100 г). Аналогично с желтозёмом типичным среднесуглинистым, обменная кислотность в гумусовом горизонте обусловлена присутствием иона водорода, в то время, как в иллювиальном горизонте - ионами алюминия; ионы алюминия появляются в том же горизонте. Показатели обменной кислотности полностью коррелируют с содержанием и распределением по горизонтам оксидов кремния, алюмосиликатов и гидроксидов железа, с максимумом в переходном горизонте $\mathrm{B}_{2}$ (свыше 83 \%) и последующим уменьшением с глубиной, и минимальным содержанием - в гумусовом горизонте А (44\%). Горизонт $\mathrm{B}_{1}$ может являться переходным АВ со значением содержания оксидов в $40 \%$.

Емкость катионного обмена постепенно уменьшается от гумусового горизонта к иллювиальному. При этом содержание всех исследованных обменных катионов распределяется с постепенным уменьшением к иллювиальному горизонту $\mathrm{B}_{2}$, и немного увеличивается к иллювиальному горизонту В3. Поглотительная способность почвы, вслед за содержанием иона водорода, уменьшается к минеральным горизонтам, насыщенность почв основаниями по всему профилю незначительна, почва относится к ненасыщенным основаниями.

Общее содержание биогенных элементов - фосфора $\left(\mathrm{P}_{2} \mathrm{O}_{5}, \%\right.$ и мг $\mathrm{P}_{2} \mathrm{O}_{5} / 100$ г), азота $(\mathrm{N}, \%)$, активного К полностью схоже с содержанием в желтозёме типичном среднесуглинистом: содержание фосфора (\%) уменьшается от гумусового к иллювиальному горизонту, а в пересчете на мг/100 г, среднее значение по горизонтам составляет 14-17 мг/100 г, распределение происходит с небольшим увеличением к нижней части профиля. Содержание азота (\%) закономерно уменьшается (вслед за содержанием органического углерода) от гумусового горизонта (AЕ) к иллювиальному горизонту $\left(\mathrm{B}_{3}\right)$.

Общее содержание элементов $\mathrm{Ca}, \mathrm{Na}, \mathrm{K}, \mathrm{Mg}$, $\mathrm{Ti}, \mathrm{Mn}$ в супесчаном лессивированном желтозёме, наряду с желтозёмом типичным среднесуглинистом не соответствует закономерному распределению, и является геохимическим признаком данного типа почв. $\mathrm{K}, \mathrm{Mg}$, Тi и $\mathrm{Mn}$ значительно превышают содержание в почве Са и $\mathrm{Na}$. Ha Mg и Тi также приходятся самые высокие значения - 2170,37 мгMg/кг и $1606,14 \mathrm{мгTi} /$ кг (схожее значение отмечается и для желтозёма типичного среднесуглинистого) - в гумусовом горизонте АЕ. Значения содержания как магния (до $169,26 \mathrm{мгMg} /$ кг), так и титана (до 3,78 мгТі/кг) резко уменьшаются в иллювиальном горизонте $\mathrm{B}\left(\mathrm{B}_{1}, \mathrm{~B}_{2}, \mathrm{~B}_{3}\right)$, подобная закономерность отмечена и для элементов $\mathrm{Ca}, \mathrm{K}, \mathrm{Na}$, $\mathrm{Mn}$, что может быть связано с физическими свойствами горизонтов $\mathrm{B}_{1}, \mathrm{~B}_{2}, \mathrm{~B}_{3}-$ увеличенным в них процента содержания тонкопесчаной фракции (миграционные свойства выше, чем у пылеватых и глинистых частиц). Высокое содержание в почве Тi, $\mathrm{Mg}$ и $\mathrm{Mn}$ в гумусовом горизонте $\mathrm{AE}$ обусловлено химическим составом почвообразующих пород (дациты) и последующей миграцией вещества из автоморфных условий в транс-аккумулятивные. 
$\mathrm{Ca}$, Na и К активно мигрируют вниз по профилю, имеют два максимума аккумуляции - в гумусовом горизонте $\mathrm{AE}$ и в иллювиальном горизонте В3. Такое распределение также может быть связано с образованием геохимического барьера в горизонте $\mathrm{B}_{3}$, в связи с изменением кислотности почвенной среды или увеличением плотности нижележащих горизонтов (С). Как отмечалось выше, $\mathrm{Ca}, \mathrm{Na}$ и $\mathrm{Mg}$, относящиеся к элементам водной миграции, в супесчаном лессивированном желтозёме, наряду с желтозёмом типичным среднесуглинистым, активно перемещаются вниз по склону из гумусового горизонта к минеральному. Причины аккумуляции К в горизонте $\mathrm{B}_{3}$ также может быть связана с увеличением плотности (увеличение содержания пылеватых и глинистых частиц) в нижележащем горизонте С.

Согласно высотной поясности, рассматриваемая территория НП Бидуп располагается в поясе верхнегорных лесов (Кузнецов, 2016). В пределах пояса происходит локальная дифференциация типов сообществ в зависимости от их местоположения. Так, на ключевом участке формируются типы лесных сообществ с разной степенью сомкнутости лесного полога, разным количеством древесных подъярусов, степенью разреженности подчиненных подъярусов и развитости яруса трав. В поймах рек формируются различной степени сомкнутости широколиственные лесные сообщества, которые вверх по склону сменяются на широколиственные лесные сообщества с менее развитым ярусом трав, а на гребне гряды представлены смешанные (сосново-широколиственные) сообщества. На склонах северных экспозиций создаются условия для накопления опада и образования лесной подстилки.

Лесному растительному покрову даны следующие характеристики: высота (м), число древесных подъярусов, сомкнутость крон (баллы 0-1) и средний диаметр деревьев в подъярусе (см), сомкнутость подроста и травяного яруса (баллы 0-1). Координаты точек описания зафиксированы с использованием GPS. Всего на площадке картографирования в НП Бидуп-Нуйба выполнено 30 полных комплексных и 86 маршрутных описаний.

Интеграция данных полевых описаний и данных аэрорфотосъёмки позволили получить карту структуры растительных сообществ для территории ключевого участка (рис. 11). Выявлено, что наиболее сложные по вертикальной структуре (4 подъяруса) древостои формируются на плоских и слабонаклонных водораздельных поверхностях рельефа. Деревья таких древостоев имеют высоту деревьев более 30 м и диаметры стволов 40-70 см, сомкнутость средняя $(0,4-0,5)$. Менее сложные древостои с 3-мя подъярусами характерны для днища долины водотока. Высота таких древостоев 30-32 м, разброс диаметров стволов деревьев 28-80 см. Древостои на склонах состоят из 2-3 подъярусов, имеют высоту 19-22 м, характеризуются средней и высокой сомкнутостью $(0,5-0,8)$.

Морфологическая структура ландшафтов. С целью изучения морфологической структуры ландшафтов территории ключевого участка было выполнено 30 комплексных фациальных описаний. Интеграция данных полевых описаний и данных беспилотной аэрофотосъемки позволила получить карту морфологической структуры ландшафтов (Котлов и др., 2018).

Согласно результатам, полученным в ходе предварительного этапа картографирования было выявлено, что рассматриваемая территория располагается в пределах Бидупского ландшафта (тропический муссонный среднегорный водораздельный хребет сильно расчленённый флювиально-эрозионно-денудационный сложенный верхнемеловыми магматическими породами с различной степенью сомкнутости вечнозелёными широколиственными лесами на ферралитных и ферсиалитных почвах), в пределах высотной местности сомкнутого литокарпусовомагнолиевого верхнегорья. В пределах изученной территории выявлено 5 типов урочищ, включающих в себя 98 типов фаций, что говорит о высоком ландшафтном разнообразии изучаемой территории. 


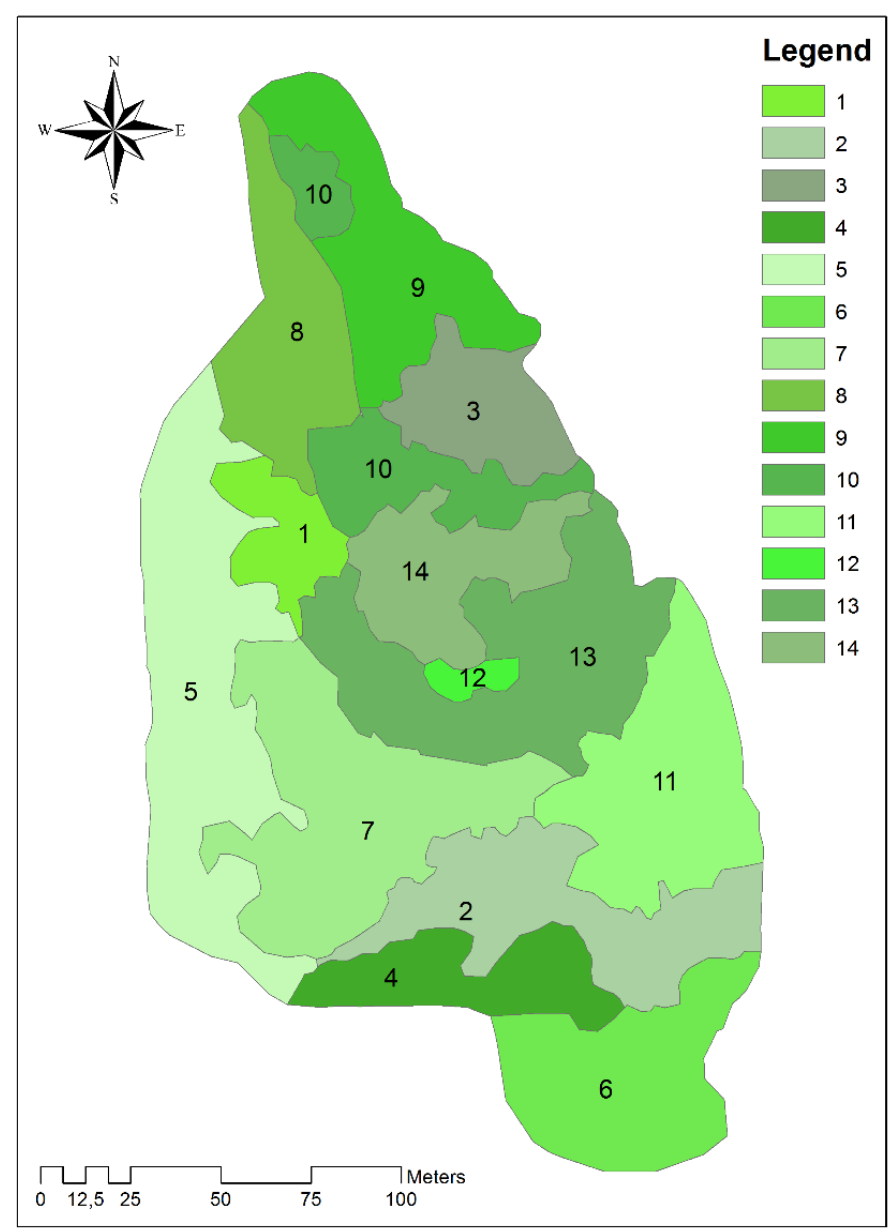

Рис. 11. Структура растительных сообществ: 1) среднесомкнутый широколиственный лес с двумя подъярусами и сомкнутым травяным ярусом; 2) сильносомкнутый широколиственный лес и смешанный (с участием хвойных - Pinus krempfii) лес с двумя древесными подъярусами и разреженным травяным ярусом; 3) разреженный широколиственный лес в пойме реки лес с тремя древесными подъярусами с хорошо развитым травяным ярусом; 4) среднесомкнутый широколиственный лес с тремя древесными подъярусами и разреженным травяным ярусом; 5) среднесомкнутый широколиственный лес с тремя древесными подъярусами и разреженным травяным ярусом; 6) среднесомкнутый широколиственный лес с четырьмя древесными подъярусами и разреженным травянвым ярусом; 7) среднесомкнутый широколиственный лес с четырьмя древесными подъярусами и фрагментарным травяным ярусом; 8) сильносомкнутый широколиственный лес с тремя древесными подъярусами и разреженным травяным ярусом; 9) разреженный широколиственный лес в пойме реки с двумя древесными подъярусами и разреженным травяным ярусом; 10) разреженный широколиственный лес в пойме реки с тремя древесными подъярусами сомкнутым травяным ярусом; 11) среднесомкнутый широколиственный лес в пойме реки с тремя древесными подъярусами и разреженным травяным ярусом; 12) среднесомкнутый широколиственный лес в пойме реки с тремя древесными подъярусами и фрагментарным травяным ярусом;13) среднесомкнутый широколиственный лес в пойме реки с тремя древесными подъярусами и сомкнутым травяным ярусом; 14) среднесомкнутый широколиственный лес в пойме реки с четырьмя древесными подъярусами и разреженным травяным ярусом.

Наличие высокого ландшафтного разнообразия, коренных типов ландшафтов, высокая динамичность процессов на выбранном участке определяют его кондиционность для создания здесь ландшафтно-экологического стационара. 
О необходимости создания Бидупского ландшафтно-экологического стационара. Ландшафтные стационары - экспериментальные полигоны, призванные выявлять особенности функционирования и динамики типичных для территории их расположения экосистем, их реакции на внешние воздействия. Сеть стационаров, расположенных на территории бывшего Советского Союза дала ряд уникальных результатов, связанных с изучением структуры и функционирования ландшафтов. Это представление о геомассах, геогоризонтах и стексах (Марктопский стационар), методика изучения динамики состояний ландшафтов (стационар Лесуново), синергетика и стратегия ландшафтов (Черногорский стационар), учение о геоэкотонах (Карадагский стационар) и др. Изначальная концепция стационаров как сети, подобной сети метеослужбы была не правильной. На наш взгляд (и здесь мы находим поддержку в работе В.Н. Петлина (2009)) ландшафтные (ландшафтно-экологические) стационары должны рассматриваться как экспериментальные полигоны, позволяющие выявлять особенности функционально-динамических процессов в ландшафтах и их реакцию на внешние воздействия. В настоящее время наиболее актуальными в данном вопросе должны быть реакции на изменения климата и оцениваться уязвимость экосистем к этим изменениям. Изменение климата, как уже давно доказано, носит региональные особенности проявления. Поэтому важным аспектом является выявление реакций и уязвимости коренных неизменённых антропогенной деятельностью экосистем на эти изменения. Хотя сегодня, вероятно, пришло время говорить о создании стационаров в том числе и в антропогенно-преобразованных ландшафтах, что связано с необходимостью адаптации системы землепользования к меняющимся реалиям. Это наиболее актуально для сельскохозяйственных, лесохозяйственных и водохозяйственных ландшафтов, наиболее подверженных климатическим изменениям.

Регион Юго-Восточной Азии, в том числе территория Вьетнама, являются слабо изученными с точки зрения функционирования и динамики ландшафтов. Сведения о структуре и функционировании лесных экосистем Вьетнама приведены в работах А.Н. Кузнецова, С.П. Кузнецовой (2006, 2011, 2013), А.Н. Кузнецова (2016), которые описали флористическое разнообразие, вертикальную структуру, высотную поясность, особенности феноритмики, особенности естественного возобновления и отдельные микроклиматические особенности различных тропических лесов, то есть создав таким образом предпосылки для изучения структуры и функционирования тропических лесных ландшафтов.

Выявление особенностей функционирования и динамики ландшафтов невозможно без знаний о структуре радиационного, теплового и водного балансов. И если данные дистанционного зондирования позволяют рассчитывать большую часть элементов балансов на основе анализа мультиспектральной съемки, функционирование ландшафтов топологического уровня возможно изучить лишь наземными инструментальными методами на специально созданных стационарах. Кроме того, мультиспектральные характеристики космических снимков позволяют определить только характеристики поверхности крон деревьев лесных сообществ, которые хоть и являются функцией процессов переноса и превращения вещества, энергии и информации в пределах лесного сообщества, но не раскрывают эти процессы, и, соответственно, не могут служить основой для описания процессов функционирования экосистемы. Это особенно актуально в горных тропических лесах, где вертикальные размеры ландшафтов могут достигать 40-50 м. А если учитывать и ландшафтный воздух, который является элементом ландшафта, то и все 100 м. В этих пределах формируется высокая степень вертикальной анизатропии, а соответственно большое количество геогоризонтов, каждый из которых характеризуется своими величинами геомасс, энтропии и т.д. 
Все перечисленные факты свидетельствуют о том, что создание ландшафтноэкологического стационара в условиях горных тропических лесов сулит множество научных открытий, получение новых знаний в области тропической экологии.

Полученные данные о компонентной и морфологической структуре ландшафтов позволяют говорить о кондиционности выбранного ключевого участка для создания ландшафтно-экологического стационара, a полученная карта морфологической структуры ландшафтов - выработать рекомендации по размещению сети измерительного оборудования.

Ключевой позицией создания ландшафтно-экологического стационара является базовая метеостанция, которая будет давать регулярные ряды данных. Стационар же, в свою очередь, может быть оснащён как стационарными измерительными системами, так и обеспечиваться полустационарными и экспедиционными исследованиями.

Изучение функционирования экосистем неразрывно связано с исследованием их радиационного, теплового и водного балансов, а также балансов вещества. Именно эти параметры определяют функционирование лесов и в тоже самое время зависят от видового состава и фитогеометрии леса, процессов трансформации вещества и энергии в лесных экосистемах (Бобра и др., 2001). Здесь следует отметить существование двух типов процессов: те, которые протекают вне зависимоти от ландшафта и являются для него фоновыми (циркуляция воздушных масс, муссоны, выпадение осадков), и те, которые формируют в ландшафте прямые и обратные связи, создавая, тем самым, особенности его структуры и функционирования.

Возвращаясь к базовой станции, одним из требований её функционирования является постоянный контроль измерительного оборудования, обеспечение его сохранности. Современный рынок метеорологического оборудования предлагает множество технических решений относительно метеостанций, не требующих развёртывания классической метеорологической площадки.

Учитывая необходимость обеспечения электрического питания и кабельной передачи данных на компьютер, наилучшим местом установки метеостанции мог бы стать лесной кордон Зянг Ли, где есть возможность обеспечения постоянного пункта приёма данных. Метеостанция устанавливается на метеомачту высотой 10 м, на вершине которой размещается анеморумбометр. Установка такого же комплекса на той же мачте на другой высоте (например, 2 м и 0,5 м) позволила бы получить градиент измеряемых параметров и рассчитывать величины параметров теплового баланса.

Кроме того, кордон Зянг Ли располагается на открытом участке и полученные значения поступления солнечной радиации будут равны величинам солнечной радиации, поступающей на верхнюю деятельную поверхность крон, что измерить иным способом проблематично в связи с высотой крон первого яруса 30 и более метров.

Базовая метеорологическая станция позволит обеспечить непрерывный ряд данных на открытом участке, что, в свою очередь, исходя из результатов экспедиционных исследований позволит рассчитать отклонения ландшафтногеофизических данных от данных базовой станции и, используя в дальнейшем данные дистанционного зондирования, экстраполировать измеряемые характеристики на большие площади. Кроме того, набор измеряемых параметров на метеостанции и выявленные в процессе экспедиции отклонения в различных типах ландшафтных фаций позволит описать особенности динамики состояний локальных экосистем различного временного масштаба и составлять карты типов состояний.

На территории стационара предлагается использование переносных портативных метеостанций во время экспедиционных исследований. Причем проведение экспедиций должно охватить все типы погодных состояний, выявленных при работе станции. Это обеспечит получение отклонений значений параметров от 

ХОЙ Н.Д.

базовой станции во всех типах экосистем и во всех возможных типах погодных состояний.

На рис. 12 представлена предлагаемая схема размещения измерительного оборудования стационара.

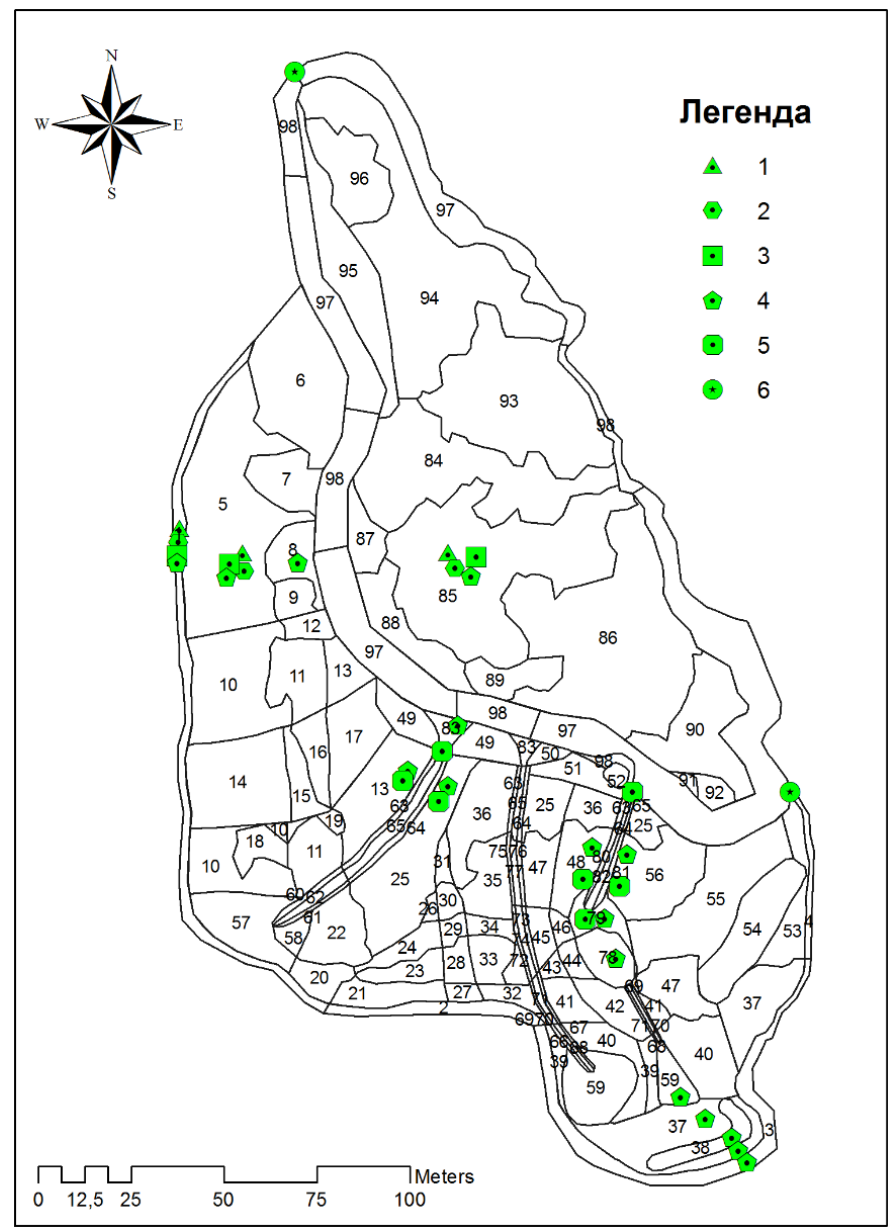

Рис. 12. Схема расположения стационарных измерительных систем в границах предлагаемого стационара: 1) актинометрические измерения; 2) температурные измерения; 3) измерения относительной влажности воздуха; 4) плювиографы; 5) микроиспарители; 6) гидрологические посты

Стационарно планируется проведение следующих измерений:

1. Актинометрические измерения (прямая, суммарная, отражённая солнечная радиация, альбедо) в различных типах лесных сообществ - необходима установка в различных типах урочищ: на гребне гряды, в средней части склона гряды, на острове; экспедиционно - измерение освещения в различных типах фаций люксометрами;

2. Температура воздуха на высоте 2 м и 0,5 м в различных типах урочищ: на гребне гряды, в средней части склона гряды, на острове. Измерения необходимо проводить термографами в психрометрических будках либо дата-логерами, экспедиционно - во всех типах фаций. В случае наличия дата-логеров - желательно покрытие ими всех типов фаций;

3. Температура почвы и лесной подстилки на разных глубинах в различных типах фаций - во время экспедиций полустационарно вытяжными почвенными термометрами;

4. Относительная влажность воздуха на высоте 2 м и 0,5 м в различных типах урочищ: на гребне гряды, в средней части склона гряды, на острове. Измерения 
необходимо проводить гигрографами в психрометрических будках либо дата-логерами, экспедиционно - во всех типах фаций;

5. Влажность почвы на разных глубинах в различных типах фаций - во время экспедиций весовым методом. Необходимо обеспечение на кордоне сушильным шкафом и весами;

6. Влажность лесной подстилки - экспедиционно в фациях, где формируется лесная подстилка;

7. Количество и интенсивность атмосферных осадков - необходима установка плювиографов в различных типах урочищ: на гребне гряды, в средней части склона гряды, на острове. Экспедиционно возможно расширение сети точек измерения с целью выявления задержания осадков различными типами сообществ за счёт использования временных осадкоприёмников.

8. Влагозапасы в почве - установка в различных типах сообществ микроиспарительного комплекса. Желательный режим измерений - один раз в месяц. Возможно автоматизация процесса за счёт установки самописца. Требуется инженерное решение.

9. Поверхностный сток воды, плоскостная эрозия, ионный сток - строительство стоковых площадок на склонах с различными типами лесных сообществ.

10. Расход воды в месте выхода из реки старицы и впадения старицы в основной водоток.

\section{Выводы}

Основными результатами первого этапа работ стало получение первичных сведений о структуре и функционировании тропических экосистем топологического уровня в горном лесном массиве.

Для территории ключевого участка составлены карты компонентной и морфологической структуры ландшафтов. Описаны условия формирования ландшафтов. Проанализированы первичные данные микроклиматических измерений.

На основе полученных результатов предложен перечень и пространственно распределённая сеть стационарных исследований на территории ключевого участка и обосновано создание ландшафтно-экологического стационара.

\section{Список литературы}

1. Бобра Т.В., Боков В.А., Ведь И.П., Гаркуша Л.Я., Зуев А.В., Клюкин А.А., Лагунов И.М., Лычак А.И., Панферов О.И., Соикова Л.М. Ландшафтно-геофизические условия произрастания лесов юго-восточной части Горного Крыма / Под ред. В.А. Бокова. Симферополь: Таврия-Плюс, 2001. - 136 с.

2. Видина A.A. Методические указания по полевым крупномасштабным ландшафтным исследованиям. - М.: Изд-во МГУ, 1962. - 135 с.

3. Геренчук K.I., Раковська Е.M., Топчієв О.Г. Польові географічні дослідження. - К.: Вища школа, 1975. - $246 \mathrm{c.}$

4. Дроздов К.А. Крупномасштабные исследования равнинных ландшафтов. - Воронеж: ВГУ, 1986. $-174 \mathrm{c}$.

5. Жучкова В.К. Организация и методы комплексных физико-географических исследований. - М.: МГУ, 1977. $-184 \mathrm{c}$.

6. Котлов И.П., Горбунов Р.В., Фам Маи Фыонг, Дин Ву Ан Ту Беспилотная аэрофотосъёмка для задач крупномасштабного ландшафтного картографирования в горных тропических лесах Вьетнама // Ландшафтная география в XXI веке: материалы международной научной конференции «Третьи ландшафтно-экологические чтения, посвящённые 100-летию со дня 
рождения Г.Е. Гришанкова» (Симферополь, 11 - 14 сентября 2018 г.) / ред. Е.А. Позаченюк [и др.]. - Симферополь: ИТ «Ариал», 2018. - С. 36-49.

7. Котлов И.П., Горбунов Р.В., Фам Маи Фыонг, Дин Ву Ан Ту Беспилотная аэрофотосъемка для задач крупномасштабного картографирования горных тропических лесных ландшафтов // Труды Карадагской научной станции им. Т.И.Вяземского - природного заповедника РАН. - 2018. - Вып. 2 (6). - С. 63-84.

8. Круглов I. Делімітація, метризація та класифікація морфогенних екорегіонів Українських Карпат // Український географічний журнал - 2008, № 3. - С. 59-68.

9. Кузнецов А.Н., Кузнецова С.П., Фан Льонг. Растительность горных массивов Би Дуп Хон Ба - южной оконечности меридионального гималайского хребта Чыонг Шон //Материалы зоолого-ботанических исследований в горных массивах Би Дуп и Хон Ба, Далатское плато, южный Вьетнам. «Биоразнообразие Вьетнама». - М.: Товарищество научных изданий КМК, 2006. -С. 9-115.

10. Кузнецов А.Н., Кузнецова С.П. Муссонные тропические леса Вьетнама (итоги 20-летних ботанико-экологических исследований) // Известия РАН. Серия биологическая. - 2013. № 2. - С. 206-216.

11. Кузнецов А.Н., Кузнецова С.П. Сукцессии в тропических лесных растительных сообществах Вьетнама // Биосфера. - 2011. - Т. 3. - № 1. - С. 50-66.

12. Кузнецов А.Н. Структура и динамика муссонных тропических лесов Вьетнама: дис. ... д. биол. наук: 03.02.01. - М., 2016. - 554 с.

13. Лопес де Гереню В.О., Аничкин А.Е., Авилов В.К., Кузнецов А.Н., Курганова И.Н. Термиты как фактор пространственной неоднородности потоков $\mathrm{CO}_{2}$ из почв в муссонных тропических лесах южного Вьетнама // Почвоведение. - 2015. - № 2. - С. 228-238.

14. Лопес де Гереню В.О., Курбатова Ю.А., Курганова И.Н., Тиунов А.В., Аничкин А.Е., Мякшина T.Н., Кузнецов А.Н. Суточная и сезонная динамика потока $\mathrm{CO}_{2}$ из почв в различных древостоях муссонного тропического леса // Почвоведение. - 2011. - № 9. - С. 1074-1082.

15. Миллер Г.П. Ландшафтные исследования горных и предгорных территорий. - Львов: Вища школа, 1974. - $202 \mathrm{c}$.

16. Околелова А.А., Тхинь Нгуен Ван, Авилов В.К. Свойства основных типов почв биосферного заповедника Донг Най (Южный Вьетнам) // Научные ведомости БелГУ. Серия Естественные науки. - 2014. - № 10 (181). - Выпуск 27. - С. 138-144.

17. Петлін В. М. Методологія та методика експериментальних ландшафтознавчих досліджень. - Львів: ВЦ ЛНУ імені Івана Франка, 2009. - 400 с.

18. Хохлова О.С., Мякиина Т.Н., Кузнецов А.Н., Губин С.В. Морфогенетические особенности почв национального парка Кат Тьен, Южный Вьетнам // Почвоведение. - 2017. - № 2. C. $176-194$.

19. Шишов Л.Л., Андроников С.В., Белобров В.П., Куленкамп А.Ю., Пантелеев Л.С., Соколов И.А. Почвы переменно-влажных тропиков Лаоса и их рациональное использование. - М.: Почв. ин-т им. В.В. Докучаева РАСХН, 1996. - 276 с.

20. Bioclimatic diagrams of Vietnam. Ed. Nguen Khanh Van et al. Hanoi: National University Publishing House, 2000. - 126 p. 


\section{ABOUT SOME PECULIARITIES OF STRUCTURE AND FUNCTIONING OF MOUNTAIN TROPICAL FOREST LANDSCAPES OF CENTRAL VIETNAM AND NECESSITY OF CREATION OF LANDSCAPE-ECOLOGICAL STATIONARY Gorbunov R.V. ${ }^{1,2,3}$, Kuznetsov A.N. ${ }^{1,4}$, Lebedev Ya.O. ${ }^{3}$, Gorbunova T.Yu. ${ }^{3}$, Kotlov I.P. ${ }^{1,4}$, Hoi N.D. ${ }^{1}$ \\ ${ }^{1}$ Russian-Vietnamese Tropical Center, Hanoi, Socialist Republic of Vietnam ${ }^{2}$ The A.O. Kovalevsky Institute of Marine Biological Research of RAS, Sevastopol Russian Federation ${ }^{3}$ T.I. Vyazemsky Karadag Scientific Station - Nature Reserve of the RAS, Kurortnoe, Feodosia, Russian Federation \\ ${ }^{4}$ A.N. Severtsov Institute of Ecology and Evolution, Moscow, Russian Federation e-mail:karadag_station@mail.ru,forestkuz@mail.ru,ya.o.lebedev@yandex.ru, gorbunovatyu@gmail.com,ikotlov@gmail.com,_danghoi110@gmail.com.}

The results of expeditionary landscape research in the territory of Central Vietnam (the national nature park Bidup Nui-Ba) are summarized. New information has been obtained on certain patterns of the structure and functioning of mountain tropical forest ecosystems. Cartographic materials illustrating the component structure of landscapes at the topological level are presented. The factors and conditions for the formation of landscapes, the morphological structure of landscapes within a key area are characterized. A network of points and programm of monitoring works based on the projected Bidoup landscape-ecological stationary is proposed.

Key words: landscape, ecosystem, landscape structure, functioning of landscapes, landscapeecological stationary, Bidup Nui-Ba, Vietnam 